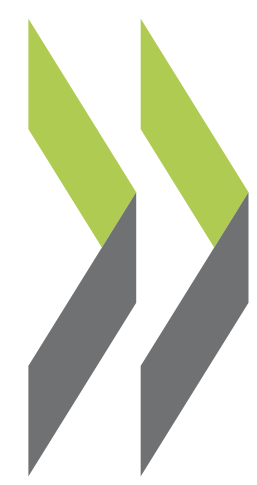

OECD Working Papers on Insurance and Private Pensions No. 35

Defined-Contribution (DC) Arrangements in AngloJohn Ashcroft Saxon Countries 


\section{\ECD}

DEFINED-CONTRIBUTION (DC) ARRANGEMENTS IN ANGLO-SAXON COUNTRIES

John Ashcroft

March 2009

OECD WORKING PAPER ON INSURANCE AND PRIVATE PENSIONS

No. 35

Financial Affairs Division, Directorate for Financial and Enterprise Affairs Organisation for Economic Co-operation and Development

2 Rue André Pascal, Paris 75116, France

www.oecd.org/daf/fin/wp 


\section{ABSTRACT/RÉSUMÉ \\ Defined-Contribution (DC) arrangements in Anglo-Saxon countries}

This paper provides a comparative analysis of defined contribution (DC) pension systems in Australia, Ireland, the United Kingdom and the United States. There are considerable similarities in the systems which have evolved out of employer sponsored trust-based defined benefit (DB) systems and have expanded at different rates as DB has declined. The plans predominantly offer individual accounts with a choice of funds, with virtually no guarantees of performance and few regulatory restrictions on investment. Most funds are heavily invested in equities, although there is a move in some of the countries to life-styling investments in the run-up to retirement. The paper finds notable contrasts between fiduciary requirements, the regulation of transparency and charges and the approach to the pay-out phase, which raise some important public policy questions.

JEL codes: G23, J32

Key words: default options, defined contribution, pension funds, private pensions.

******

\section{Systèmes de pension à cotisations définies dans les pays anglo-saxons}

Ce document présente une analyse comparative des systèmes de pension à cotisations définies en Australie, en Irlande, au Royaume-Uni et aux États-Unis. Il existe de grandes similitudes dans les systèmes à cotisations définies qui tendent à remplacer les systèmes d'entreprise à prestations définies gérés par des «trusts », selon des rythmes différents à mesure que la part des systèmes à prestations définies se réduit. Les plans à cotisations définies sont essentiellement bâtis sur des comptes individuels qui offrent un choix de fonds sur lesquels investir. Ils n'apportent pratiquement pas de garantie de performance et les contraintes réglementaires en matière de placements auxquelles ils sont soumis sont limitées. La plupart des fonds sont fortement investis en actions, bien qu'on assiste au développement, dans certains pays, de fonds à horizon dont le portefeuille d'investissements se modifie à mesure que le souscripteur approche de la retraite. L'étude relève des différences notables dans les exigences fiduciaires, dans les règles de transparence et dans les frais mis à la charge des participants, ainsi que dans les modalités de déblocage de l'épargne, ce qui soulève d'importantes questions dans l'optique de l'action des pouvoirs publics.

Codes JEL : G23, J32

Mots clés : options par défaut, cotisations définies, fonds de pension, pensions privées.

\section{Copyright OECD, 2009}

Applications for permission to reproduce or translate all, or part of, this material should be made to: Head of Publications Service, OECD, 2 rue André-Pascal, 75775 Paris Cédex 16, France. 


\title{
DEFINED-CONTRIBUTION (DC) ARRANGEMENTS IN ANGLO-SAXON COUNTRIES
}

\author{
By John Ashcroft ${ }^{1}$
}

\section{Executive Summary}

This paper reviews work-based defined contribution pensions in four countries selected as representatives of the 'anglo-saxon' tradition in private pension provision: Australia, Ireland the UK and the USA. Each country comes from a common starting point of employer-sponsored trust-based defined benefit provision which has, at varying speeds, been shifting to a DC model. While the regulatory frameworks and practices have been diverging, some common trends are still evident:

\section{General}

- Government provided (first pillar) pensions are paid at a lower replacement rate than in most OECD countries, placing a greater incentive on individuals to make their own pension provision, usually through their work-place.

- DC provision is increasingly replacing DB and the majority of employees accruing pension provision are doing so through DC.

- Employers remain extensively involved in sponsoring DC plans and assuming fiduciary responsibility for them through the appointment of trustees or supporting multi-employer plans.

- The trust-based approach provides employers with considerable flexibility, with only limited legislative constraint in designing pensions products.

- There has, however, been a strong recent trend towards contract-based arrangements where the employer's role is simply to facilitate individual employee contracts with commercial providers, although the flexibility available to such arrangements varies.

- While there is generally only limited regulation of DC product design, each country has developed a more heavily regulated and simplified product aimed at situations where employers default their employees into a plan, although the Australian and Irish products have not become as popular as the others.

- Nearly all DC benefits are based solely on contributions and investment returns for individual accounts - minimum guarantees or risk pooling apply to only a small minority of provision.

\footnotetext{
${ }^{1}$ John Ashcroft is an independent consultant to the OECD. The views expressed herein are those of the authors and do not necessarily reflect those of the IOPS or its members. The authors are solely responsible for any errors.
} 
Interestingly, the main exception, is the relatively unsuccessful Australian (contract-based) capital guaranteed product known as a Retirement Savings Account that can be made available by deposit taking institutions and life insurance companies outside of a trust structure.

\section{Contributions}

- There has been a trend towards increasing enrolment to DC plans through compulsory contributions (in Australia, and the UK from 2012), compulsory provision and facilitating autoenrolment into plans.

- While the provision of tax relief is a major driver of the approach to pension provision, direct Government contributions exist only in Australia and the UK and are relatively small.

- It is most common for both employer and employee to contribute to a DC pension with median contributions totalling just over $10 \%$ of salary, but mean contributions being somewhat higher reflecting a significant tail of members with much higher contribution levels.

- Contribution levels tend to rise with size of employer and age of employee. They also tend to be higher for trust-based than contract-based plans.

- A minority of plans in each country other than Australia have arrangements to increase contribution levels over time.

\section{Investment}

- Most plans use third parties to provide the funds in which member balances are invested, and investment in unitised products is very common.

- Fear of fiduciary liability for investment decisions has been an important driver of behaviour (except it would appear in Australia).

- Most plans offer members a choice of fund with contract-based plans offering considerably more choice than trust-based. Outside the US at least, plans with fund choice usually offer a default fund even where, as is often the case, this is not a requirement. It would appear that the most common US practice is for members to spread investments across funds.

- Most members, including those in default funds, are at least $70 \%$ invested in growth investments, primarily equities. This is because commonly used balanced or consensus funds include that level of growth assets.

- Consequently, most members achieve strong returns most years that are subject to considerable volatility. Net returns appear to be higher for larger plans and trust-based plans, reflecting differences in asset allocation and the level of charges.

Fees

- While there is a wide range of fee structures, most of the fees charged are levied as an annual management charge.

- Fee levels are unregulated for most plans covered by this survey, with effective regulation of transparency limited to Australia and specified products in Ireland and the UK. Except possibly 
for PRSAs in Ireland and group personal pensions in the UK, regulation does not appear to have been a significant direct driver of fee levels for employer sponsored plans.

- The major drivers of fee levels appear to be whether the plan is trust-based or commercially provided and whether funds are passively or actively managed, both factors that appear to add $0.2-0.4 \%$ to overall cost levels. Additionally, employers bear the administrative costs of UK and Irish and many US trust-based plans.

\section{Payout rules}

- There is little similarity across these countries, except that there are generally tax advantages to keeping the larger part of pension accumulations within the pensions system.

The following key differences have opened up between the four countries surveyed:

\section{Contributions}

- There are different degrees of compulsion, from Australia's requirement that employers contribute $9 \%$ of salary to a pension plan, through differing requirements for pension plans to be made available in Ireland and the UK, through to none at all in the USA. US participation rates nonetheless appear to be at least as high as in Ireland and the UK.

- There is a differentiation between Australia and Ireland where fixed employer and employee contributions are most common, and the UK and USA where employer matching of employee contributions, albeit normally with a minimum employer contribution, is the norm.

\section{Investment}

- The general preference for balanced funds with a large (say two thirds or more equity component) is not shared by a significant minority of US plan members who hold more conservative portfolios, or members of the majority of UK default funds which are $100 \%$ equity allocated

- The USA differs from the other countries in the much lower (although growing) use of default funds, and the common use of conservatively invested default funds.

- The preference for active fund management found in Australia and the USA is not found in Ireland and the UK, where (lower cost) passive investment strategies are most common.

- Life-styled default funds are the norm in the UK and for Irish contract-based plans and are becoming more common in the USA, but have yet to become significant in Australia, for US plans without auto-enrolment or for Irish trust-based plans.

Fees

- Plans in the USA, PRSAs in Ireland and retail plans in Australia appear to be outliers from the general trends elsewhere, with fees applied to members' balances commonly exceeding $1 \%$. The absence of any effective regulation of fee levels of transparency in the USA may have had some impact on the reputedly high level of investment management charges there. 


\section{Payout rules}

- It is easier for members to remove savings from the pension system pre-retirement (or take out loans) in the USA than in the other countries, especially Ireland and the UK.

- At retirement, there is a big differentiation between Australia and the USA, where the whole balance can be taken out or rolled-over into continuing growth-seeking investment, and Ireland and the UK where annuities or income drawdown products must be bought with the larger part of the balance. Australia is further differentiated by the ability to rollover balances within the existing plan

- On the other hand, life annuities are rare in Australia and taken up by a fairly small minority of retirees in the USA

- Excepting income drawdown products, there is effectively therefore a distinction between a system that is mostly DC pre and post retirement in Australia and the USA, and one that is DC pre-retirement moving to DB post-retirement.

- Members who opt to roll-over balances or take income drawdown appear mostly to be settling for a similar (balanced) fund allocation for pre and post retirement savings, and hence a very different risk profile from those who annuitise. This goes some way to explaining the varying prevalence of fund life-styling.

It can be seen that the similarities between pension provision in the countries considered are greater than the differences. The fundamental differences that do exist would bear some further analysis:

- $\quad$ The US system provides members with much greater ability to withdraw (or borrow from) their accumulated balances than the others. Is this 'leakage' justified by an increased willingness to contribute to pensions compared with the UK and Ireland despite having no requirement on employers to make a plan available? Will the increasing popularity of auto-enrolment change the balance of advantage?

- There is some evidence of a material difference in the outcomes achieved by those plans that are run by trustees appointed by employers and those which are run by commercial providers, albeit that, as for Australian retail plans, they may have trustees. The former would appear to be less conservatively invested and have lower fees, which results in better performance in good years at the expense of higher risk of downside. The lower fees for members generally come at a cost to the employer. It would be worth exploring whether the not-for-profit trust-based model outperforms commercially provided plans even allowing for bad years and the cost to the employer.

- The prevalence of active and passive fund management varies between countries. There is some limited UK evidence that net returns from passively invested funds tend to exceed those for actively managed funds. There must therefore be a question mark over the popularity of active management in Australia and the US, especially for those funds that are effectively default funds. Further analysis might indicate whether this is a serious issue.

- The extent to which default funds are offered varies, which may affect outcomes for those members not well qualified to make a rational choice. Is there a strong enough case to recommend that they be made compulsory, (as will be the case in the UK from 2012) and are there lessons that can be disseminated on desirable design features for such plans? Furthermore, 
can highly conservative default funds be avoided and should steps be taken, as in the USA (Pension Protection Act 2006), to render them unnecessary?

- Most significantly, perhaps, the relationship between the way pensions savings are invested in the accumulation and payout phases varies markedly, with several different models which seek to make the two phases consistent and reduce cliff-edge effects on transition.

- One model (in Australia and the USA) has balanced investment continuing throughout the working life with a post-retirement investment plan, which may include a drawdown plan thereafter, and with any move to more conservative investment taking place then, but with no guarantee of a lifetime income;

- The other model (in the UK and Ireland (especially PRSA)) has life-styled funds shifting investments, held initially predominantly in growth assets, into alignment with the prevalent annuity and cash payout mechanism

- For other members, the alignment between the two phases appears less obvious. It would be interesting to explore the comparative advantages of the different models and to consider whether conclusions can be drawn at least about significantly sub-optimal models.

- Finally, there are large (and different) gaps in the data on DC plans available in all the countries surveyed. It is hard to see how regulators can ensure that their pensions systems are delivering optimal outcomes and minimising exposure to avoidable risks in the absence of the data needed to make decisions. 


\section{Introduction}

This paper has been prepared for the OECD to provide comparative information on the regulation of private sector defined contribution (DC) plans across four selected OECD countries falling within the "anglo-saxon" tradition: Australia, the Republic of Ireland, the United Kingdom and the United States of America. The terms of reference are set out in appendix 1.

The paper contributes to a wider-ranging project on "risk measures for DC pension plans" being undertaken by the OECD in collaboration with Allianz Global Investors (AGI), with input from Risklab Germany and the OECD. This paper is an element in Part I of the project that gives an overview over all relevant current DC pension systems, analyzes their key-characteristics and documents their driving properties

The findings in this paper have been derived from published sources, referenced where relevant, along with the author's personal knowledge of how DC plans are regulated in the anglo-saxon tradition. All monetary values are expressed in euros (with appropriate rounding) using conversion rates (reflecting approximate May 2008 rates) of:

- $€ 1=£ 0.79$

- $€ 1=\mathrm{US} \$ 1.55$

- $€ 1=$ Aus $\$ 1.64$

The rest of this section provides general background to the anglo-saxon tradition in private pensions and to the systems in each of the countries surveyed. Following sections cover plan contributions, investment, fees and the payout phase, in each case outlining regulation and practice across the four countries. Supporting details are tabulated in Appendix 2.

\section{The "anglo-saxon" tradition}

The starting point for the anglo-saxon tradition was the voluntary provision by employers, from the late $19^{\text {th }}$ century, of employee benefits in the form of pensions to reward loyal service and facilitate staff recruitment and retention. These, entirely voluntary, arrangements developed before any specific legislation was passed and hence had to adapt the most relevant legal structures already available, trust law. At an early stage, governments sought to encourage provision by providing tax relief for employer or employee contributions and accumulations within the plan, or in Australia some relief on accumulations coupled with relief on post-retirement payments from the plan. (an approach found in Australia. Hence, plan design and behaviour has been influenced by tax legislation, and this needs to be understood to understand the arrangements. Indeed, in the USA the predominant form of DC plan, the $401 \mathrm{k}$, is a creation of tax law.

Substantial provision had already developed before governments decided that more specific regulatory legislation was needed. The legislation therefore had to respect what was already present, and avoid providing disincentives to voluntary provision. As governments have become keen to raise participation in private pensions they have imposed other types of arrangement within the pre-existing systems, which have therefore become increasingly complex and diverse. 
Private pension arrangements within the anglo-saxon tradition share much in terms of legal systems and legislative arrangements, in particular the important role of trust and tax law and a relatively nonprescriptive approach to legislation. The essential elements in common are:

- Trusts established by employers to run their pension plans have, until relatively recently at least, been the predominant form of pension plan governance - which means that trust law still plays a key role in governance, and legislation need not duplicate safeguards that arise automatically from the fiduciary responsibilities of the trustees.

- The rules of pensions trusts determine how each plan is run, the benefits paid out etc, although legislation can over-rule them if it is specifically drafted so to do. Trust rules may impose more restrictive requirements on members than allowed by legislation or disallow options allowed by legislation.

- Each country has had a large number of trust-based pension plans, the majority of which are very small, although some much larger multi-employer schemes have also appeared

- Private pension provision has become a standard part of remuneration packages for all but small employers and therefore a major source of citizens' retirement income, with aggregate plan assets exceeding 50\% of GDP in all four countries. This compensates for the relatively low level of government provided pensions, with replacement rates from this source being below the OECD average in all four countries.

- While defined benefit (DB) provision was traditionally predominant, there has been a strong trend since the 1980s for that provision to be closed to new members, or simply not be offered by new employers, with a shift instead into defined contribution (DC) arrangements provided by employer-sponsored pension trusts, sometimes as a separate section of a DB trust

- More recently, commercial financial services companies (commonly insurers) have entered the market by selling individual DC plans directly and through the employer.

- Whether provided by trusts or commercially, DC plans are mostly 'pure' DC - there is no (or only a minimal amount) element of guarantee as to the eventual size of pension, exposing members to the full investment performance risk, possibly with some limited smoothing.

It should be noted that the countries in this survey are not the only countries from the anglo-saxon tradition - Canada, Kenya, New Zealand and South Africa also have well established private pension arrangements. But the four countries selected provide a good spread of the divergence of practice that has developed within the tradition, while providing a good example of specific features that are not necessarily found in private pensions arrangements developed in different traditions.

\section{Concepts and scope}

This paper only covers the systems of private pensions provided primarily by private sector entities and uses the relevant OECD concepts and terms to refer to them. Some key concepts that are especially relevant in the anglo-saxon tradition do need to be defined in the next few paragraphs.

For the purpose of this paper, a Defined Contribution (DC) pension plan is defined as an arrangement into which members pay contributions into a (notional or actual) individual account, to which may be added contributions from an employer. The contributions are used to purchase a share of the investments held by the plan which can be constituted into one or more funds with differing asset 
allocations. The accumulated gross returns on the allocated investments, less any administrative charges and investment fees, constitute the members' stake in the plan which can (or has to) be used at retirement to finance a vehicle for paying out income during retirement. (In some jurisdictions the plan itself can be the vehicle). Most of the plans referred to in this paper provide no guaranteed minimum return, and the paper does not generally cover DC plans with substantial underpins, or other forms of 'hybrid' or risk sharing plans. These are considered to be DB in the anglo-saxon tradition.

The primary focus of this paper is on DC private pensions to which employers can, and usually do, make contributions. Hence they are delivered or promoted through the workplace as an employee benefit. They contrast with DC pension plans which individuals choose to take out separate from their employment (or as self-employed individuals). The paper passing refers to plans for which employers collect employee contributions but without adding their own contributions or taking on any other responsibilities. The latter category includes DC plans (called additional voluntary contributions) which employers in the UK and Ireland provide to enable employees to supplement their DB pensions. Contribution rates to such plans tend to be relatively low. In practice, it is not always easy to obtain separate statistics for pension products sold to individuals and those sold through the workplace and some data covers both.

In the anglo-saxon tradition DC plans delivered through the workplace fall into two broad categories:

- plans where the employer, or trustees he appoints, have an explicit fiduciary role, albeit that the precise nature of this role and the fiduciaries varies from country to country. The member's relationship is with the employer through the employment contract and with the plan trustees. For the purpose of this paper these plans are described as trust-based; and

- contract-based plans where there is an individual contract between each member and a commercial provider and the role of the employer is intended to be limited to encouraging employees to join and paying over employer and employee contributions. They are commonly regulated as savings not pensions products (or as both).

While this distinction is important, it is blurred in the case of retail superannuation plans in Australia which are trust-based, but with trustees appointed by the commercial provider, and involve the employer to the same limited extent as a contract-based plan.

For both categories, individual accounts are backed up by pooled investments packaged into one or more funds from which members can commonly (but not always) choose. For trust-based plans the performance of these funds may be smoothed by using reserves (but this hardly ever happens outside Australia and even there the practice is declining). The investment of the funds and the administration of the plans is commonly outsourced to separate commercial organisations. A contract-based plan is always separate from the investment and management functions which are undertaken by the commercial provider, which could in OECD terminology be described as a pension fund. To avoid confusion with the funds in which members can choose to invest, they will be referred to as pension providers not funds in this paper.

\section{Key features of DC pension arrangements in the countries surveyed}

Despite the strong similarities between private pensions in the four countries in the survey, the systems have been steadily diverging and some of the differences are now more significant than the similarities. The private pension systems in each of the four countries are summarised below. 


\section{Australia}

Australia started off with the anglo-saxon trust-based model of (primarily DB) private pension provision . By the 1980s employers were already starting to make trust-based DC provision available. In 1992, Australia introduced the anglo-saxon tradition's first private pension system with mandatory employer contributions. From that point, nearly all employees ${ }^{2}$ had to be enrolled into a trust-based superannuation plan or contract-based Retirement Savings Account (RSA).

Superannuation plans are nearly all DC, with only a few 'legacy' DB plans remaining (although many DC plans have a residual DB section). Plans are either company or industry-based multi-employer plans or commercially provided pensions products sold by commercial pension providers operating under a master-trust. Retail plans and most industry-wide plans can be offered by employers with no connection with the plan, so long as they have been licensed as 'public offer' plans.

Employers and employees can instead contribute to commercially provided Retirement Savings Accounts. These must provide a guaranteed minimum return (with returns usually much less than a superannuation fund) and are targeted in particular at low earners who are intrinsically less attractive to public offer funds.

Since 2006 the trustees of all superannuation plans with five or more members have had to be licensed by the supervisor, the Australian Prudential Regulation Authority (APRA), which also supervises the providers of RSAs. The introduction of licensing has been accompanied by a substantial reduction in the number of pension plans, down to about 550 by 2008, along with professionalisation of plan management, which is commonly in the hands of trustee companies (albeit with lay employer and member appointed directors on the trustee board where the plan is employer-sponsored or industry-wide). There are additionally thousands of self-managed superannuation plans, with under five members all trustees, mostly supervised by the tax authority ${ }^{3}$.

\section{The Republic of Ireland}

Ireland has employer-sponsored trust-based plans, (including a few industry-wide plans) which have progressively shifted provision from DB to DC, so that at least half their private sector members have DC rights ${ }^{4}$. There is also contract-based DC provision in the form of Retirement Annuity Contracts (RACs) (although these can be and occasionally are set up under trust) and, since 2003, Personal Retirement Savings Accounts (PRSAs). PRSAs are a State established and regulated product that can be sold through employers. In practice most of the regulatory requirements fall only on 'standard' PRSAs, the default pension plan for employers offering no other form of provision.

The supervisory (and regulatory) authority is the Pensions Board for all pension plans (including single member plans), of which there are around 98,000 DC plans, of which 217 have 100 or more members (and 1,400 DB). The Irish Financial Services Regulatory supervises RACs. The Board shares responsibility for PRSA supervision with the tax authority.

\footnotetext{
${ }^{2}$ The requirement covers employees aged 18-70 earning over $€ 275$ a month.

${ }^{3}$ APRA also supervises some 5800 funds with fewer than five members which do not meet the requirements for regulation by the tax office.

${ }^{4}$ Figures from the 2007 Pensions Board Annual Report give 530,000 DB members, just under half of which are in the private sector and 270,000 DC members. There were some 130,000 PRSA accounts of which around 45,000 were arranged through the employer
} 


\section{United Kingdom}

The UK has a broadly similar system of trust-based and contract-based provision to Ireland, although the number of trust-based DB members far exceeds DC trust-based membership ${ }^{5}$. This is partly because contract-based provision has become more significant than in Ireland, and indeed is the main growth area for private pension provision. The "stakeholder" pension, introduced in 1999, plays a similar role to the PRSA in Ireland - other personal pensions are called either that or self invested personal pensions (SIPPs). The Pensions Regulator supervises some 80,000 trust-based DC plans, of which only a few hundred have over 1,000 members, plus a further 2,200 (often larger) plans which have DC and DB sections. It also supervises the employer-related aspects of all work-based pensions. The Financial Services Authority has the lead role in supervising personal pensions, and shares the supervisory role with the Pensions Regulator for stakeholder pensions.

The Government intends to introduce, from 2012, a new quasi-mandatory individual DC pensions savings account ("personal accounts") to be delivered by a State-sponsored pensions trust. All employers will have to offer this to their employees, and make contributions unless the employees opt out. This new scheme is not considered in any depth in this paper.

USA

The USA requires that all pensions to which employers contribute (and receive tax benefits) be delivered on behalf of a sponsor by fiduciaries, and makes them subject to the Employee Retirement Income Security Act 1974 (ERISA). The Act defines a fiduciary as anyone who exercises discretionary control or authority over plan management or plan assets, anyone with discretionary authority or responsibility for the administration of a plan, or anyone who provides investment advice to a plan for compensation or has any authority or responsibility to do $\mathrm{so}^{6}$. This means that nearly all employersponsored plans can be loosely defined as trust-based. Traditionally these plans were employersponsored DB trusts, some which have replaced or supplemented their DB plans with DC plans. Such DC plans take the form of profit sharing, money purchase, stock option or target saving plans (this list is not exhaustive). In the traditional versions of these plans employers make tax-deductible contributions but employees cannot ${ }^{7}$.

If employers wish to establish a plan to which employees contribute they must establish either a " $401 \mathrm{k}$ " plan ${ }^{8}$ or facilitate the provision of individual retirement accounts. The $401 \mathrm{k}$ plan is an individual pensions savings account available only to employees (including the self-employed) with rules established by US tax legislation, as well as being covered by ERISA, although employers with no more than 100 employees can establish a SIMPLE plan that avoids many its requirements.. The sponsoring employer must nominate a plan trustee to hold the assets and can contribute by means of matching

5 The Pensions Regulator's 2006/07 figures show around 14 million private sector DB members - the DC membership figure for that year is around 2.7 million. To compare like for like the 4.6 million pensioner members need to be excluded from DB memberships in which case they fall to a level about double that for DC.

${ }^{6}$ Plan fiduciaries include, for example, plan trustees, plan administrators, and members of a plan's investment committee. They also include the employer, where as is usually the case, it retains investment responsibility

${ }^{7}$ Employees can make post-tax contributions and EBSA statistics show that a small number do.

${ }^{8}$ The name refers to Section $401 \mathrm{k}$ of the US tax code that since 1980 has allowed these plans. While a different section of the tax code (403b) applies to some not for profit entities, the provisions are similar and the term $401 \mathrm{k}$ is commonly applied to all plans of this nature. 
contributions (hence profit-sharing plans cannot be 401k but can be, and mostly are, combined with them ${ }^{9}$ ). $401 \mathrm{k}$ plans can otherwise include most types of DC design.

Contract-based individual retirement accounts started off as a retail product. Employers can offer them to staff without assuming fiduciary responsibilities only if they are standard retail products with standard charges, the employer makes no contributions and they conform with some other requirements. If they have no more than 100 employees and no other pension provision they can make contributions and still keep just a limited fiduciary role by using a SIMPLE IRA plan which allows employee contributions, subject to tighter than usual limits on contribution levels. They can also offer a SEP IRA with employer contributions only.

While employer sponsored IRAs are a small but growing part of the workplace pension market, in aggregate, the balances in IRAs exceed those in $401 \mathrm{k}$ plans, totalling around $€ 2.6$ billion. This is partly as a result of individual investment, but also because members are allowed, or often compelled, to withdraw their balances from their $401 \mathrm{k}$ at change of employment or retirement, and the greater part (over $80 \%$ ) of these balances rolls over into IRAs. These transfers totalled $€ 160$ billion in 2005, about the same as the total DC contributions that year, and have since risen to $€ 190$ billion in $2007^{10}$. While IRAs are a key element in many employees' pension plans, there is only limited information about them as they are not supervised in the same way as pension plans.

There are some 630,000 DC plans with more than one participant, of which some 430,000 are 401k plans and some 67,000 plans $(57,000$ of the $401 \mathrm{ks})$ have 100 or more participants. Regulatory and supervisory responsibilities for employer-sponsored plans are divided between the Department of Labor and the Internal Revenue Service.

\section{Scale and importance}

To obtain a feel for the scale and importance of the different forms of DC provision in each country, Table 1 (in Appendix 2) provides recent approximate figures for the memberships and assets of DC plans (with DB figures for comparison). Using this data, Figure 1 gives an indication of the relative scale of different types of plan membership, and Figure 2 the size of the DC sector relative to the employed workforce.

\footnotetext{
${ }^{9}$ Money purchase plans cannot be combined with a 401k.

${ }^{10}$ Source for IRA data, Cerulli Associates: IRA rollover and retention: strategies and positioning (September 2008). Aggregate pensions data from Private Pension Plan Bulletin Abstract of 2005 Form 5500 Annual Reports published by Department of Labor, February 2008.
} 


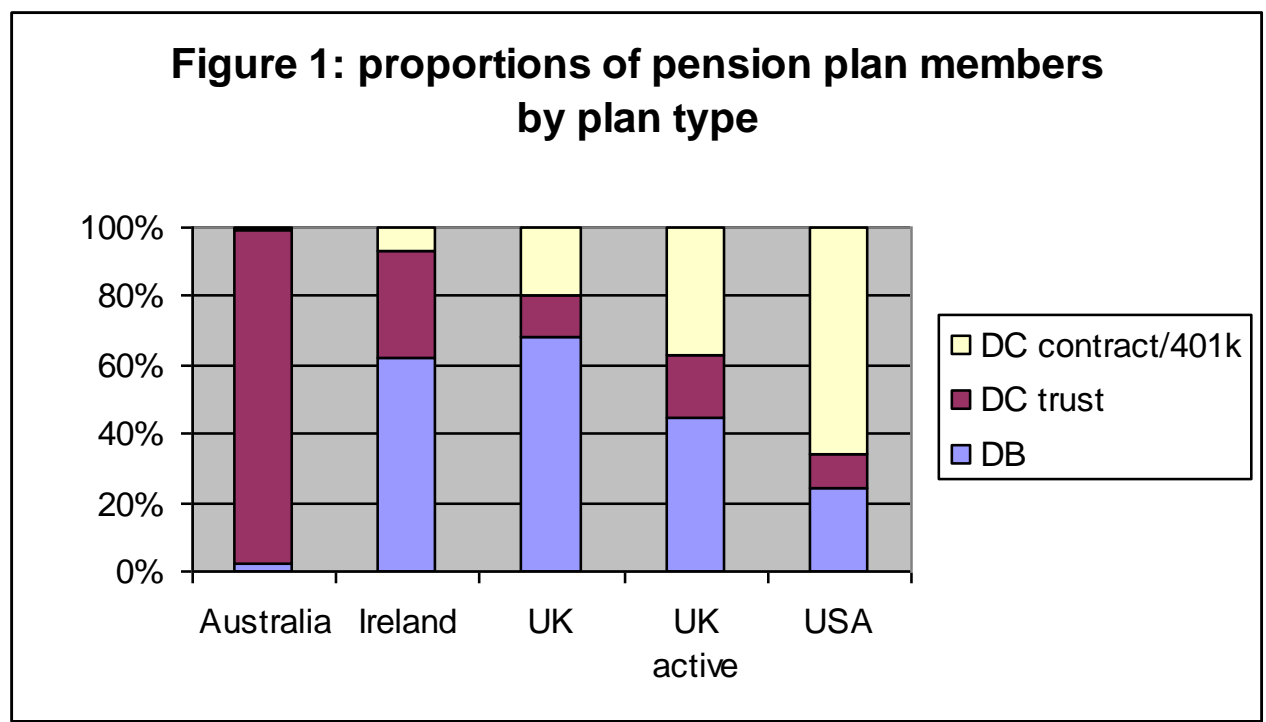

Notes: The figures for Australia exclude most public sector plans which have a further 2 million memberships.

The UK figures include 4 million pensioner members of DB plans. These plans also have large numbers of deferred members. Excluding these, and deferred members of DC plans, gives a more accurate comparison. It should be noted that the figures for UK contract-based plans are particularly approximate.

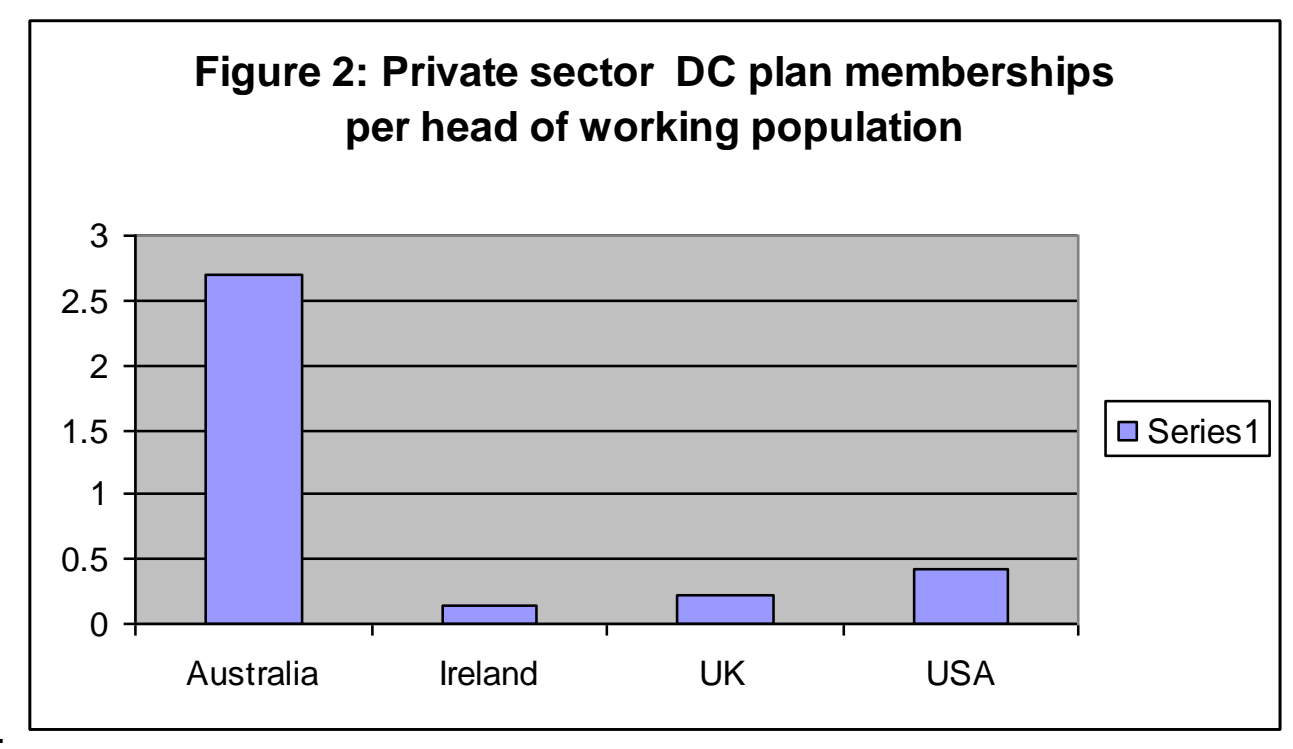

Note: The figures include non-contributing members of plans but, where possible, exclude members of public sector plans. 


\section{Contribution Policy}

\section{Availability of DC pension plans}

Before considering the requirements on employers and employees to contribute to pension plans, it is necessary to consider requirements on employers to make plans available. Three countries (Australia, Ireland and the UK) require employers to make a pension plan available, although the UK requirement currently only applies to employers with five or more employees (all employers are intended to be covered from 2012). The USA has no such requirement, but the proportion of the private sector workforce with active work-based plans is higher in the USA than in Ireland and the UK.

While legislation in the countries concerned does not specify which type of plan has to be made available, and hence DB plans can discharge the availability requirement, the default provision is DC. In the UK and Ireland the default is a specifically regulated contract-based product, the stakeholder pension and standard PRSA respectively, the key design features of which are outlined in Box 1. Where an employee wishes to join the designated plan, the employer is obliged to make deductions from employee salary and pay these over to the plan provider within legislatively specified timescales, even though the employer need make no contribution.

In Australia the default is a superannuation plan or contract-based retirement savings account. While the USA does not require employers to make a pension plan available, it has established a tighter regulatory framework for employer-sponsored DC plans that auto-enrol employees and therefore need to provide a default fund. . This is a 'safe harbor' plan where employers do not have fiduciary responsibility for the investment losses of members in the default fund ${ }^{11}$, see Box 1.

A common theme therefore is that each country considers it important to have specific product regulation of a design of DC product that an employer can safely offer as a default when it is obliged to offer a plan or wishes to auto-enrol, without having to take any fiduciary responsibility. In Australia, the UK and Ireland the product is a form of contract-based provision, although the Australian product is relatively unattractive because a capital guarantee underpins it - assets in these accounts are less than $1 \%$ of the assets in superannuation plans.

The UK Government intends to introduce a new pensions product from 2012, Personal Accounts, which employers will have to make available in default of any other equivalent or better provision. This will replace stakeholder pensions as the default product, and the future status of stakeholder pensions is unclear.

\footnotetext{
${ }^{11}$ Pension Protection Act 2006
} 


\begin{tabular}{|l|l|}
\hline Box 1: regulated DC product designs \\
\hline UK & $\begin{array}{l}\text { The stakeholder pension was introduced as the simple contract-based default pension scheme } \\
\text { to be offered by employers with five or more employees and no other pension provision, who from } \\
2001 \text { are required to make a pension available (although not contribute to one). It also serves a } \\
\text { simple retail personal pension and has increasingly been provided by employers in place of or } \\
\text { alongside existing provision. There is a charge cap of 1.5\% of fund value, falling to } 1 \% \text { after } 10 \\
\text { years, and a default fund with life-styling is mandatory. The responsible manager at the provider } \\
\text { has fiduciary responsibilities, along with some specific regulation of disclosure and investment. }\end{array}$ \\
\hline Ireland & $\begin{array}{l}\text { The standard Personal Retirement Savings Account (PRSA) is likewise the contract-based } \\
\text { default provision for (all) employers required (since 2003) to make pensions provision. It must also } \\
\text { be offered by employers who do not offer any other form of additional voluntary contribution } \\
\text { arrangement on top of their DB scheme. There must be a default fund in which investments are } \\
\text { limited to pooled funds, with certification by an actuary as to its appropriateness (which appears, } \\
\text { inter alia, to have been largely interpreted as a requirement for life-styling). There is a charge cap } \\
\text { of 5\% of contributions and 1\% per annum of fund value }\end{array}$ \\
\hline USA & $\begin{array}{l}\text { The 'safe-harbor' 401k plan, introduced in 2007, is the only scheme available to employers } \\
\text { wishing to auto-enrol into a scheme without falling foul of any contrary State legislation or or } \\
\text { incurring fiduciary liability for investment performance. It requires that there should be a default } \\
\text { fund of one of three designs, effectively diversified funds with life-styling (including target } \\
\text { retirement date funds) or aiming for a balance between capital preservation and long-term } \\
\text { appreciation (target return funds). Members may only be enrolled into the default after being given } \\
\text { the option of fund choice and financial education. Investment in the employer is prohibited. The } \\
\text { plan can be developed further to avoid (anti-discrimination) legislation restricting the amount of } \\
\text { accrual for high earning employees so long as regulations on minimum employer contributions are } \\
\text { met. }\end{array}$ \\
\hline
\end{tabular}

\section{Contribution requirements and limits}

Only Australia currently requires employers to contribute to a pension plan and none of the countries in this survey currently require that employees contribute to a plan. Australia requires employer contributions of at least nine per cent of salary for employees earning over a minimum threshold ${ }^{12}$ and aged 18 to 70 .

Legislation in Ireland, the UK and the US prevents employers from accepting employee contributions into traditional open trust-based DC plans (not 401k's) without themselves making a contribution. In the UK employers must also contribute at least 3\% to group personal pension plans to avoid having to offer a stakeholder pension alongside it. It is intended that the UK Personal Accounts scheme will, once fully operational, require a three per cent employer contribution and four per cent employee contribution, (plus a 1\% contribution from the tax authority) unless the employee opts out (with restrictions on the eligibility of low earners and under $23 \mathrm{~s}$ ).

The US additionally applies a non-discrimination test to all trust-based plans (except SIMPLE 401k plans) to prevent more than a specified amount of the benefits going to high earners. This test can be avoided if there is an employer contribution of at least $3 \%^{13}$ with a minimum initial employee

\footnotetext{
${ }^{12}$ The threshold is a salary of $€ 274$ (Aus\$450) a month

${ }^{13} 3.5 \%$ where it is a matching contribution
} 
contribution of $3 \%$ rising to $6 \%$ by the fourth year. For SIMPLE IRAs employers must either contribute $2-3 \%$ fixed or $1-3 \%$ matched with employee contributions ${ }^{14}$.

The only other restrictions on contribution levels are maximum limits on employer and employee contributions (detailed in Table 2 in Appendix 2). The limits are very high in the UK (100\% of salary or $€ 285,000$ on tax deductibility) relatively high in Australia and the US (around $€ 30,000$, but much lower for SIMPLE plans ${ }^{15}$ ) while Ireland has an age-dependent salary-related limits, starting with $15 \%$ for the youngest employees. These limits have little practical impact for most employees.

\section{Participation levels}

Active participation in Australian retirement savings plans is estimated at $90-95 \%$. Overall private sector participation levels vary across the other three countries, with the US just over $50 \%$ and the UK and Ireland around $40 \%^{16}$. In all three countries the majority of active participants are now believed to be in DC plans, with the US having $43 \%$ of the workforce in them, and around half that proportion contributing to DC plans in the other two countries. Table 3 in Appendix 2 gives more details.

The prevalence of automatic enrolment is likely to be a key factor influencing participation. Australia's mandatory system results in 90-95\% auto-enrolment, while the level of auto-enrolment has been rising in the USA, to around $30 \%$ of DC plans. There is conflicting data on auto-enrolment into UK DC plans, with one figure giving 33\% of DC members in such plans while other figures suggest a much lower level. It is legal and quite common for Irish employers to make plan membership compulsory and hence to auto-enrol employees.

\section{Contribution practices}

The contribution structure is determined by plan rules and there is considerable latitude as to what these may stipulate. There are in practice five main models of plan contributions, illustrated in Figure 3:

- Plans where most or all contributions come from the employer, because employee contributions are not tax-deductible and may not be allowed by the plan rules. Such plans are found only in the US, where they cover around $16 \%$ of DC memberships ${ }^{17}$.

- Plans where employers and employees make fixed contributions only - the most common model in Australia and Ireland.

\footnotetext{
${ }^{14}$ The employer matching contribution cannot go below $3 \%$ for more than 2 calendar years out of a 5-year period

${ }^{15}$ Note that the Australian limit on non-tax deductible contributions is much higher (around €90,000) while the US limit for employee contributions to SIMPLE $401 \mathrm{ks}$ and IRAs in the US is $€ 6,800$ (with some scope for additional contributions up to $€ 1,600$ for employees aged 50 or over).

${ }^{16}$ Figures published in September 2008 in the Quarterly National Household Survey produced by the Irish Central Statistics Office show that $54 \%$ of the Irish population between ages 20 and 69 have some pension provision. This is, however, not necessarily inconsistent with the $40 \%$ active participation rate quoted in this paper from other sources, as it includes people who have contributed to a pension but no longer do so. On the other hand, it is not clear from the US statistics as to whether significant numbers of members are not participating.

17 The figures are for all DC plans that are not established under tax code article 401k and cover memberships, as individuals may belong to more than one plan. Source: US Department of Labor statistics for 2005.
} 
- Plans where the employer and employees contribute an agreed minimum amount with scope for further employee contributions which are usually matched to some extent by the employer. This is the most common form of provision in the UK and the USA ${ }^{18}$ and can also be found in Ireland. There is no evidence of such provision in Australia.

- Plans where the employee has to contribute (for the plan to be active) and the employer may choose to match some of these contributions to some extent. For US 401k plans, employees have to contribute a specified percentage of income and the plan must specify the extent, if any, of employer contributions. This is also the model for a few contract-based plans in Ireland and the UK (stakeholder pensions only in the latter). Trust-based plans in Ireland would not attract tax benefits unless the employer made a contribution.

- Plans where both the employee and the employer have discretion as to what contributions, if any, they make each year. This can be achieved in the US by a combination plan, which combines a profit sharing plan, to which only the employer contributes, but on a discretionary basis, and a 401k plan to which the employee contributes, but can choose not to in any given year (so long as there is no employer contribution). This design is not found elsewhere.

Figure 3: availability of different degrees of employer and employee contributions

\begin{tabular}{|l|l|l|l|}
\hline Employer & Employee & Mixed & Matching \\
\hline Fixed & None & Aus, Ire, UK, US & AUS, Ire, UK, US \\
\hline Matching & Aus, Ire, UK, US & - & $\begin{array}{l}\text { US, Ire, UK } \\
\text { (PRSA/stakeholder) }\end{array}$ \\
\hline Fixed \& matching & - & - & Ire, UK, US \\
\hline Profit sharing & - & US combination plan only & $\begin{array}{l}\text { US combination plan } \\
\text { only }\end{array}$ \\
\hline None & US & $\begin{array}{l}\text { Ire (mainly RAC), UK } \\
\text { (stakeholder), US }\end{array}$ & - \\
\hline $\begin{array}{l}\text { Coding: bold = most common in that country, red = quite common in that country, italic = possible but not very } \\
\text { common in that country }\end{array}$
\end{tabular}

In practice, most DC plans receive contributions from both employers and employees. While it is possible for an employer-sponsored DC plan in the UK, Ireland (contract-based plan only) or the USA (401k) to be funded only by employee contributions, most of these plans also have employer contributions. Indeed, the impact of the legislation in the UK and Ireland requiring that employers make pension plans available has been muted because many employers have been unwilling to make contributions and employees therefore also have not contributed. This has resulted in a large number of 'shell' plans, with a designated employer sponsor and fund provider, but no assets ${ }^{19}$. As retirement annuity contracts in Ireland rarely receive employer contributions, they are unusual as employersponsored plans - employers almost always contribute to their UK counterparts' (group personal pensions) ${ }^{20}$ and hence they are widespread and growing.

Plans that can receive only employer contributions are a minority in all the countries surveyed.

\footnotetext{
${ }^{18}$ In the US this model is required of safe-harbor plans intended to avoid anti-discrimination provisions.

${ }^{19}$ Available figures from end 2006 suggest that only $15 \%$ of the $46 \%$ of Irish employers that offer a PRSA make contributions and that less than $2 \%$ of employees make a contribution to a PRSA.

${ }^{20}$ The Employer's Pension Provision Survey 2005 indicates that at least 94\% of employers offering a group personal pension make contributions to it.
} 
For all these models it is standard practice for contribution levels to be set as a proportion of salary, except for US profit-sharing plans. Matching formulae are the most common means of determining employer contributions in the UK and USA, in the former case often with an employer minimum regardless of the level of employee contribution. Fixed percentage employer contributions are most common in Australia and Ireland. A minority of plans in Ireland have arrangements to enable fixed employee contributions to increase with age. $8 \%$ of UK employers with contributory DC plans have arrangements to escalate pension contributions over time, with $29 \%$ of employers with trust-based plans having such arrangements and much smaller percentages of employers with contract-based plans Table 4 gives further details.

In addition to employer and employee contributions there is some limited government funding in Australia and the UK:

- In Australia the State matches employee contributions from low and medium earners up to a maximum of $€ 915$ a year for employees earning $€ 17,000$ a year or less and lesser amounts tapering off with earnings until they reach $€ 35,400$ a year - an arrangement that has benefited some 1.2 million members since its introduction in 2003. These contributions nonetheless represented less than 1.5 per cent of total contributions in 2006.

- In the UK the government adds a rebate to private pension contributions where the employee is contracted out of the (pay-as-you-go) state Second Pension to compensate for the consequential loss of benefits. The operation of this system is complex, and for DC plans, no longer generally considered to provide full compensation to most members for loss of State second pension. For contract-based pensions, the rebates appeared to represent around $19 \%$ of contribution income in $2005 / 06^{21}$. The level of contracting out has been falling substantially in recent years, and is probably below the 2006 figure of $11 \%$ of DC plans ${ }^{22}$.

\section{Levels of contributions in practice}

In order to understand the impact of DC plans in the surveyed countries, it is necessary to look at details of average and aggregate levels of employer and employee contributions and their relationship with member salaries and age. Unfortunately data on DC contributions is limited, and what little global data that exists needs to be supplemented by survey data. This is especially a problem for contract-based provision which may not be disaggregated from the personal pensions data, where available at all. Different data elements exist in the countries surveyed which renders precise comparisons difficult.

The available figures are provided in Table 5 and summarised in Figure 4 below. It should be noted that, where known, median contribution rates are mostly lower than mean levels, reflecting a significant tail of contribution levels well in excess of the mean. In summary:

- Employers contribute widely varying amounts where they are free to so, but contributions to trust-based plans average around 6-8\% of salary in Ireland and the UK, around 9\% in US profitsharing plans and around 14\% in Australia. Employer contributions to (UK and Irish) contractbased plans and US 401k plans are a little bit lower, even where the employer contributes, and this appears to be true even after making allowance for the smaller size of employers with these arrangements. Many employers contribute well above these levels, with large employers

\footnotetext{
${ }^{21}$ HMRC statistics May 2007. Figures for trust-based plans are not readily available.

${ }^{22}$ Association of Consulting Actuaries smaller firms survey 2006
} 
commonly contributing around $1-2 \%$ more than the average, and many plans having contributions in the $10-13 \%$ range.

- Employees contribute differing amounts according to plan type and nationality, although there appears to be a common trend of percentage contributions rising with age (where evidence is available).

Figure 4: average contribution levels

(all figures as percentages)

\begin{tabular}{|c|c|c|c|c|c|}
\hline & \multicolumn{2}{|c|}{ Employer } & \multicolumn{2}{|c|}{ Member } & \multirow{2}{*}{$\begin{array}{c}\text { Total (most } \\
\text { common) }\end{array}$} \\
\hline & Contributions & Contributing & Contributions & Contributing & \\
\hline Australia & 14 & 100 & 3 & Assumes 100 & 17 \\
\hline Ireland (trust) & 6 & 100 & 5 & most & 11 \\
\hline $\begin{array}{l}\text { Ireland (contract) } \\
\text { median member }\end{array}$ & 7 PRSA only & $\begin{array}{c}10 \text { (PRSA) } \\
0 \text { (RAC) }\end{array}$ & 7 & 100 & 7 \\
\hline UK (trust) - & $6-8$ & 100 & $4-5$ & 87 & $10-13$ \\
\hline UK (contract) & $5-7$ & $\begin{array}{c}65 \\
\text { (stakeholder) } \\
95 \text { (GPP) }\end{array}$ & 3 & 100 & $8-10$ \\
\hline $\begin{array}{ll}\text { USA } & \text { (profit- } \\
\text { sharing) } & \\
\end{array}$ & $9^{23}$ & 100 & 0 & & 9 \\
\hline $\begin{array}{l}\text { USA } \\
\text { (Combination) }\end{array}$ & 5 & 100 & $5-7^{24}$ & & $10-12$ \\
\hline USA (401k) & 3 & 95 & & 100 & $8-10$ \\
\hline
\end{tabular}

Note: total contributions show aggregate average contributions for plans where the majority of both employers and members contribute, or the employer/member contribution level only where only a minority of plans have contributions from both.

\section{Conclusions}

While the provision of tax relief is a major driver of the approach to pension provision, direct Government contributions exist only in Australia and the UK and are relatively small. Most member accounts receive contributions from both the employer and the member, although there is a significant minority of plans (UK stakeholder and Irish contract-based) without employer contributions and a fairly small proportion of US plans without member contributions. (Employer contributions are required for trust-based and non 401k plans in every country). Fixed level contributions predominate in Australia and Ireland, matching predominates in the UK and is common in the USA, where an element (at least) of employer contributions is profit-related. A minority of plans (outside Australia) arrange for member contribution levels to increase over time (as a default).

Contributions to DC plans vary considerably within and between the countries surveyed. One key factor is the trend towards increasing enrolment to DC plans through compulsory contributions (in Australia, and the UK from 2012), compulsory provision and government encouragement in the USA of auto-enrolment into plans. Overall contributions tend to be in the $8-12 \%$ range with employer contributions, except for Australia (higher where members contribute) and lower where there is no

${ }^{23}$ Only $5 \%$ of plans offer a fixed contribution - nearly all the rest link employer contributions to the level of profits, which means that this figure can in principle vary markedly from year to year. In practice the average did not deviate by more than $0.8 \%$ from $9 \%$ between 2002 and 2005 .

${ }^{24}$ Just over $5 \%$ for lower paid employees and $7 \%$ for higher paid employees, for employee receiving tax relief on contributions (as opposed to those in the ROTH scheme where tax relief attaches to payouts). 
employer contribution. There is a significant tail of members with much higher contribution levels than those shown above. Contribution levels tend to rise with size of employer and age of employee.

\section{Plan investment}

\section{Regulated choices and default options}

In all the countries surveyed plans are allowed to offer a choice of funds - in Australia this extends to compulsory choice between pension plans and hence funds. The requirements for providing default plans where choice is offered vary as follows:

- Since July 2005 Australian employers have been required to offer fund choice either by offering more than one plan, or in some circumstances a plan with fund choice. The mandatory nature of the pension system means that some form of default fund is unavoidable although an explicit default fund is not mandated. Instead plans can decide how to allocate members who do not wish to make a choice on the basis of personal details provided.

- In Ireland trust-based plans that offer fund choice must assign default status to one or more of the funds they offer as choices ${ }^{25}$. Standard PRSAs in Ireland must offer one or more funds with a default investment strategy which the PRSA actuary must certify complies with legislative requirements. ${ }^{26}$

- Stakeholder plans in the UK must offer a life-styled default fund and from 2012 all plans that wish to be eligible to employees instead of the new personal accounts will have to offer a default fund.

- Where US plans covered by ERISA offer fund choice there must be at least three different investment options so that employees can diversify investments within an investment category, such as through a mutual fund, and diversify among the investment alternatives offered. In addition, members must be given sufficient information to make informed decisions about the options offered under the plan. Participants also must be allowed to change investments at least once a quarter, and perhaps more often if the chosen investment option is extremely volatile.

- US requirements can go further where employers auto-enrol their employees into a plan without taking on fiduciary responsibility for the performance of the unavoidable default fund. To obtain a safe-harbor in such circumstances they must offer a default fund that complies with explicit regulatory requirements (see Box 1 and above).

\section{Regulatory restrictions on investment decisions}

The 'prudent person' principle underpins the regulatory frameworks in anglo-saxon countries. Hence there are few specific restrictions on how pension plans can invest. Instead, there is considerable reliance on the fiduciary role, fitness and propriety of the pensions trust or the management of the pension provider, i.e plan governance. The restrictions that do exist cover:

\footnotetext{
${ }^{25}$ This requirement comes from Schedule I to the disclosure regulations (SI 301/2006) which requires the trustees to disclose the 'one or more' funds to which payments will default, while giving the plan freedom to make the choice of a fund or distribution between funds at the time of investment.

${ }^{26}$ Irish employers with trust-based plans are, however, required to offer a (DC) additional voluntary contribution arrangement, or failing that a standard PRSA for additional member contributions. These are not employer funded.
} 
- Investment in the sponsoring employer (self-investment);

- Investment in illiquid or high risk products;

- Diversification of investment; and

- Investment in the period before retirement.

Australia, Ireland and the UK forbid more than 5\% of the market value of trust-based plan resources being invested in the sponsoring employer ${ }^{27}$. In Australia, no self-investment is allowed by public offer superannuation funds, except for life insurance policies and certain other exemptions. While there is a blanket $10 \%$ restriction in the US, this can be waived for employee stock ownership plans and 401k plans where the rules so specify ${ }^{28}$, except for the default fund in safe-harbor plans, where such investment is not allowed for employee contributions ${ }^{29}$. Around $15 \%$ of DC members belong to an employee stock ownership plan (a 401k plan for 85\% of participants), and 2005 statistics showed employer-related investments to be around $30 \%$ of such plans' total assets ${ }^{30}$. In practice, well under $5 \%$ of the aggregate investments in other types of plan are employer-related ${ }^{31}$, although the percentage exceeds $5 \%$ for plans with 5,000 or more members. Indeed $15 \%$ of the assets of such plans are invested in company stock funds ${ }^{32}$.

Restrictions on investment in illiquid or high risk products are as follows:

- In Ireland and the $\mathrm{UK}^{33}$, the assets of trust-based schemes must consist 'predominantly' of investments admitted to trading on regulated markets. Investment in assets which are not admitted to trading on such markets must be kept to a 'prudent' level ${ }^{34}$. Investment in derivative instruments may be made only in so far as they contribute to a reduction of risks or facilitate efficient portfolio management (including the reduction of cost or the generation of additional capital or income with an acceptable level of risk). Any such investment must be made and managed so as to avoid excessive risk exposure to a single counterparty and to other derivative operations.

\footnotetext{
${ }^{27}$ UK: Pensions Act 1995, as amended by the Occupational Pension Schemes (Investments) Regulations 2005. This is a requirement of the EU pensions (IORP) directive

${ }^{28}$ Subject to limits on employee contributions being invested in the employer

${ }^{29}$ Employer stocks can be held by a mutual fund or similar regulated investment fund in which the plan invests so long as this is consistent with the stated investment objectives of the vehicle. It may also hold employer securities provided as employer matching contributions.

${ }^{30}$ EBSA statistics for 2005 - plans with 100 or more members

31 EBSA statistics for 2005 show $€ 180$ billion employer-related investment, of which over $€ 140$ billion is in employer stock ownership plans. The remaining less than $€ 40$ billion compares with total assets of some $€ 1,300$ billion for those plans.

${ }^{32}$ Source: Profit sharing/401k Council of America (PCSA): 50th annual survey of profit sharing and 401k plans, reflecting 2006 plan experience.

${ }^{33}$ All these provisions are set out in the respective Occupational Pension Schemes (Investments) Regulations 2006 in Ireland, and 2005 regulations with the same title in the UK. The wording is mostly identical - the UK wording is used here.

${ }^{34}$ For the purposes of these regulations an investment in a collective investment scheme is treated as an investment on a regulated market to the extent that the investments held by that scheme are themselves so invested and a qualifying insurance policy is treated as an investment on a regulated market.
} 
- The UK and Irish provisions for stakeholder pensions and standard PRSAs go even further, as the former must be invested in assets traded in regulated markets ${ }^{35}$ and the latter in unit funds.

- There are no specific restrictions in Australia and the USA beyond the general requirements outlined below.

Specific regulation of investment diversification is as follows:

- In Australia, requirements are limited to those for risk management and investment strategies, as trustees are expected to consider diversification in preparing the strategy.

- In Ireland and the $\mathrm{UK}^{36}$, the assets of a trust-based plan must be properly diversified in such a way as to avoid excessive reliance on any particular asset, issuer or group of undertakings and avoid accumulations of risk in the portfolio as a whole. Investments in assets issued by the same issuer or by issuers belonging to the same group must not expose the scheme to excessive risk concentration $^{37}$. Similar provisions apply to UK stakeholder pensions and, effectively, PRSAs.

- In the US, ERISA requires fiduciaries to diversify the investments of the plan so as to minimize the risk of large losses, unless under the circumstances it is clearly prudent not to do so.

- Also in the US, schemes wishing to take advantage of safe-harbor protection must have a qualified default fund that applies generally accepted investment theories and is diversified in a way so as to minimise the risk of large losses through a mix of equity and fixed income exposures. Asset allocation should be consistent with a target level of risk consistent with the circumstances of all members or of each individual member (see below).

There is additionally a life-styling requirement on UK stakeholder pensions that in the five years (at least) before the member's retirement date the assets in the default fund of the plan should be gradually transferred into interest bearing deposits or government securities so as to reduce the member's exposure to volatility ${ }^{38}$. This reflects the risks arising from the liquidation, and mostly annuitisation, of plan assets upon retirement. The only equivalent requirement in the other countries surveyed applies to one of the three permitted US qualified default investment alternatives (see below) which requires the member's fund to become more conservative in the years running up to retirement.

\section{Governance requirements}

The anglo-saxon tradition relies much more on the responsibilities of fiduciaries and disclosure to members than on specific investment limits to ensure that plan investment is in members' interests. It can be seen from the regulations above, that even where specific restrictions are placed on investment, the phraseology often leaves considerable room for discretion through the use of words such as 'predominantly' and 'prudent' (see above).

\footnotetext{
${ }^{35}$ Or cash returning at least base rate minus 2\% (Stakeholder Pension Schemes Regulations 2000).

${ }^{36}$ As note 29

${ }^{37}$ To the extent that the assets of a scheme consist of qualifying insurance policies, those policies are treated as satisfying the requirement for proper diversification.

${ }^{38}$ This applies only to members joining the plan on or after 6 April 2005.
} 
The US practice deviates somewhat from that in the other countries in that the employer can be, and commonly is, responsible for investment decisions, albeit delegating this role to investment managers, leaving the trustee(s) to administer the plan and secure custody of the assets. The trustees may in practice be managers of a commercial provider. In the other countries the employer is not permitted to direct investment strategy, and legislation is more prescriptive as to the governance of the trust.

In summary, the main regulatory governance requirements on investment by trust-based plans to ensure that members interests are protected cover:

- the fitness and propriety of trustees;

- trustee and adviser conflicts of interest;

- taking investment advice from suitably qualified professionals and entrusting day-to-day investment decisions to professional investment managers;

- putting in place appropriate risk management arrangements, including internal controls, specified in varying levels of detail; and

- preparing and following investment strategies, see below.

Trustees in Australia, Ireland and the UK have to prepare an investment strategy (in the latter two countries called a 'statement of investment principles' (SIP)). Australia has the most specific requirements relating to the strategy, which must have 'regard to all the circumstances of the entity', including in particular:

- the risk involved in making, holding and realising, and the likely return from, the plan's investments, having regard to its objectives and expected cash flow requirements;

- the composition of the plan's investments as a whole, including the extent to which they are diverse or involve exposure of the plan to risks from inadequate diversification;

- the liquidity of the plan's investments, having regard to its expected cash flow requirements;

- the ability of the plan to discharge its existing and prospective liabilities.

The SIPs required in Ireland and the UK (a requirement of the EU IORP Directive) must be reviewed every three years or immediately after a change in investment policy. The trustees must obtain appropriate professional advice and consult the employer. In Ireland the SIP need simply cover the trustees' investment objectives, the investment risk measurement methods, the risk management processes to be used, and the strategic asset allocation implemented with respect to the nature and duration of pension liabilities. In the UK it must cover the trustees' policy for securing compliance with their general legislative duties relating to investments ${ }^{39}$ and their policies on:

- the kinds of investments to be held;

- the balance between different kinds of investments;

\footnotetext{
${ }^{39}$ Section 36 of the Pensions Act 1995
} 
- risks, including the ways in which risks are to be measured and managed;

- the expected return on investments;

- the realisation of investments; and

- the extent (if at all) to which social, environmental or ethical considerations are taken into account in the selection, retention and realisation of investments ${ }^{40}$.

Similar provisions regarding the SIP apply to UK stakeholder pensions. In Ireland the standard PRSA Default Investment Strategy must reflect 'general good practice for investment for retirement' and be certified as such by the PRSA actuary. In addition, trustees in Ireland are required to invest the assets of the scheme in a manner designed to ensure the security, quality, liquidity and profitability of the portfolio as a whole so far as is appropriate having regard to the nature and duration of the expected liabilities of the scheme.

In the US, the legislative (ERISA) requirements of fiduciaries are high level and principle-based and simply require that fiduciaries must:

- establish a prudent process for selecting investment alternatives and service providers to the plan;

- ensure that fees paid to service providers and other expenses of the plan are reasonable in light of the level and quality of services provided;

- select investment alternatives that are prudent and adequately diversified; and monitor investment alternatives and service providers once selected to see that they continue to be appropriate choices.

It is left to fiduciaries to make appropriate arrangements to comply with these duties including those relating to diversification. In practice, at least $80 \%$ of US profit sharing and $401 \mathrm{k}$ plans have an investment policy statement. ${ }^{41}$

\section{Disclosure requirements}

A major focus within the regulation of retail financial products in the anglo-saxon countries is on providing members with accurate information to facilitate the exercise of investment choice. This applies to contract-based DC products sold through the workplace. Hence, the intermediaries facilitating the sale and employer choice of contract-based DC are covered by rules on the information they must disclose. The providers are covered by a similar rules-based regime, supplemented in the UK, by the principle-based regulatory requirement of 'treating customers fairly'.

The legislative frameworks for trust-based DC tend to have a different starting point, and there is some variation in the extent to which the effective provision of information is mandated:

- In Australia, plans must annually provide a personal member benefit statement giving information on opening and closing balances (and the termination value at closing date where

\footnotetext{
${ }^{40}$ A UK SIP must also cover the policy on exercising voting rights if one exists - it is not mandatory.

${ }^{41}$ Source: PCSA: 50th annual survey of profit sharing and $401 \mathrm{k}$ plans, reflecting 2006 plan experience.
} 
different), benefit entitlements, increases in contributions, return on investment and changes in circumstances relating to the investment, the management and performance of the scheme and basic information about the product.

- In Ireland, plans offering DC fund choice must provide members with a general description of each fund's investment objectives, risk and return characteristics and the type and diversification of assets comprising the portfolio of the fund ${ }^{42}$. The plan must also provide all active DC members with an annual Statement of Reasonable Projection which should be prepared by an actuary in accordance with professional guidelines ${ }^{43}$.

- In the UK, the plan, or for contract-based arrangements the provider, must provide each member who has contributed or for any other reason whose benefits have changed significantly, and exceed $£ 5,000$, a statutory money purchase illustration indicating the amount of pension that may be payable by means of annuity (with caveats), in line with professional actuarial guidance on the subject.

- In the US, there is a requirement that (safe-harbor) plans that auto-enrol employees must give participants written notice before the default investment kicks in and annually thereafter. The legislation requires the notice to be written in a manner that can be understood by the average plan participant. Such plans must also provide financial education.

\section{Safe-harbours}

A key driver for employer and fund behaviour in this area is a concern that fiduciaries will be held liable for investment under-performance of a fund into which they have defaulted members. This issue has been most pronounced in the US where fiduciaries are explicitly absolved of liability for DC plan performance so long as the participant exercises control over the investments in their account and receives sufficient information and fund choice options (three) to enable this process ${ }^{44}$. Any form of default fund (and hence auto-enrolment) would fall foul of this. There is a view in the UK, at least, that courts might apply a similar view, absent specific legal requirements. This situation has resulted in more cautious employers (with group personal pensions) or trusts not offering a default fund. A few UK and (it is understood $)^{45}$ many US trust-based plans have offered a conservative cash/bond default fund to minimise the risk from the fund and encourage active choice.

Where members have been obliged to exercise choice, they have often responded (in the US at least) by spreading investments across a number of funds, concentrating investment in equity funds, often active equity funds that could well have lower net returns than passive funds ${ }^{46}$, or investing in company stock ${ }^{47}$.

\footnotetext{
${ }^{42}$ Schedule I to the disclosure regulations (SI 301/2006)

${ }^{43}$ Some of the provisions only become effective for trust-based plans in January 2009

${ }^{44}$ ERISA section $404(\mathrm{c})$

${ }^{45}$ This reference, and the suggestion in paragraph 4.17 is taken from Watson Wyatt "The default dilemma: what to do when DC members cannot or will not choose an investment option" 2008 , but reflects comments made in other sources.

${ }^{46}$ See UK evidence for lower net performance of active funds below.

${ }^{47}$ Conclusions drawn from: Individual Account Investment Options and Portfolio Choice: Behavioral Lessons from 401(k) Plans - Prepared for the June 2006 Trans-Atlantic Public Economics Seminar - Jeffrey R. Brown and Scott Weisbenner (University of Illinois at Urbana-Champaign and NBER), Nellie Liang (Federal Reserve Board of Governors).
} 
There have therefore been some regulatory developments to provide employers and other fiduciaries with relief from liability, in particular from the choice of default fund, in exchange for more prescriptive regulation of investment choice and governance. The approaches to such relief varies:

- There is no relief in Australia. Indeed, the supervisor has warned that those trustees which allow unconstrained member investment direction could be subject to claims from any members who invest unwisely and thereby reduce their future retirement income.

- Irish disclosure regulations (2006) for plans offering investment choice enable provisions in scheme rules that allow trustees to claim safe-harbour but also require the provision of a default fund and specified information about fund characteristics and fees.

- UK plans other than stakeholders can avoid selecting a default fund, but only the legislation for stakeholder plans provides the employer with relief from liability for investment performance ${ }^{48}$.

- Even if US fiduciaries follow the legislative requirements relating to member choice referred to above, they retain responsibility for selecting investment managers and monitoring fund performance. They can relieve themselves of fiduciary responsibility for any default fund offered by complying with the safe-harbor regulations (Box 1 above and below).

The types of safe-harbor default allowed in the US push members towards more sophisticated funds with some risk mitigation. They can be plans that seek to reduce risk approaching retirement, that is lifestyled or target retirement date funds, balanced funds that target a particular level of risk "that is appropriate for participants of the plan as a whole" and managed funds with one or other of the above objectives. Early evidence suggests that the target date fund is becoming prevalent ${ }^{49}$.

\section{Investment choice and defaults funds in practice}

Figure 5 summarises the available data on the extent of fund choice and prevalence of default funds in practice. It is common practice for plans to offer fund choice although the average number of choices varies from 5 for Irish trust-based plans to 92 for Australian retail plans. In practice, plans in Australia and the US often offer members the opportunity to develop a bespoke fund choice by spreading investments between the funds offered. Where data is available it shows that a significant proportion of plans offer 20 or more funds.

Most pension plans in the countries surveyed (except probably in the USA) offer a default fund choice even where this is not a requirement (which it is for Irish trust-based plans and PRSAs, UK stakeholders, US auto-enrolment plans and effectively for Australian plans ${ }^{50}$ ). Furthermore, where offered, most the contributions of most employees in the UK and Australia are invested in the default fund (through choice or inertia) and it is highly likely that this pattern is found elsewhere.

\footnotetext{
${ }^{48}$ Section 3(8) of the Welfare Reform and Pensions Act 1999

${ }^{49}$ Allocations to the funds will grow to 56 percent of assets in all defined-contribution plans by 2011, up from 11 percent this year [2007], estimates the TowerGroup, a Needham, Massachusetts-based research and consulting firm. Another commentator (at the 2008 NAPF conference) suggested that they constitute around $70 \%$ of auto-enrolment defaults.

${ }^{50}$ See footnote 52.
} 
Figure 5: default funds and fund choice in practice

\begin{tabular}{|c|c|c|c|c|c|}
\hline & \multicolumn{2}{|c|}{$\%$ of plans with } & \multirow{2}{*}{$\begin{array}{l}\% \text { of members in } \\
\text { default fund } \\
\text { (where offered) }\end{array}$} & \multicolumn{2}{|c|}{$\begin{array}{l}\text { Number of funds offered (where fund } \\
\text { choice) }\end{array}$} \\
\hline & fund choice & default fund & & Median & $\begin{array}{l}\% \text { plans with > } \\
20\end{array}$ \\
\hline Australia & $\begin{array}{l}65^{51} \\
>90 \text { (by plan } \\
\text { assets) }\end{array}$ & $\begin{array}{l}45 \text { (by } \\
\text { assets) }\end{array}$ & $\begin{array}{l}\text { Around } 80 \text { mean } \\
90+\text { median plan }\end{array}$ & $\begin{array}{l}6 \text { (company) } \\
9 \text { (industry-wide) } \\
92 \text { (retail) }^{54}\end{array}$ & $\begin{array}{l}\text { Around } 40 \text { for } \\
\text { plans with assets } \\
>€ 60 \text { million }\end{array}$ \\
\hline Ireland & $87^{56}$ & $\begin{array}{l}100 \quad \text { (legal } \\
\text { requirement) }\end{array}$ & $\mathrm{n} / \mathrm{a}$ & $\begin{array}{l}5 \\
\text { PRSA similar) }\end{array}$ & $\mathrm{n} / \mathrm{a}$ \\
\hline $\mathbf{U K}^{5 /}$ & 89 & 81 & $\begin{array}{l}\text { 79\% mean } \\
88 \% \text { median plan }\end{array}$ & $\begin{array}{l}11 \text { (Mean 14) for } \\
\text { trust-based } \\
50 \text { contract-based) }\end{array}$ & $\begin{array}{l}23 \quad(10 \%>40) \\
\text { trust-based } \\
\text { Most for contract- } \\
\text { based }\end{array}$ \\
\hline USA $^{58}$ & $\begin{array}{l}94 \text { employer } \\
\text { contributions } \\
98 \text { member } \\
\text { contributions }\end{array}$ & $\mathrm{n} / \mathrm{a}$ & $\mathrm{n} / \mathrm{a}$ & $\begin{array}{l}17 \text { for employer } \\
\text { contributions } 18 \text { for } \\
\text { member } \\
\text { contributions }\end{array}$ & 19 \\
\hline
\end{tabular}

\section{Fund investment in practice}

Because the regulatory framework for investment is relatively light touch, investment behaviour in practice is mainly determined by the market. Most DC plans invest in unit funds provided by investment management companies (trust-based) or the investment products of financial services institutions providing contract-based plans or indeed the assets of trust-based plan (a very common arrangement for the many small plans in Ireland, the UK and USA). Only a few plans invest directly, (for instance only

\footnotetext{
${ }^{51}$ APRA statistics for 2007, excluding retail plans not involved with main-stream superannuation and public sector plans. The 10-year overview in 2006 shows that the figures are higher for plans with assets of over $€ 60$ million, being respectively $75 \%, 92 \%$ and $84 \%$ for company, industry-wide and retail plans.
}

${ }^{52}$ Because membership of a pensions plan is compulsory for most employees, plans have in practice to allocate members who do not make an investment choice to a default fund. Strictly speaking, however, this does not require a designated default fund as some plans selecting the default according to information about personal and financial circumstances submitted by employees when they join.

${ }^{53}$ Rainmaker 2008 gives the mean - Rice Warner 2006 the median. The latter shows well over half of surveyed default funds having over $90 \%$ of plan membership. APRA statistics, however, indicate that less than $50 \%$ of plan assets for retail plans are in the default fund, compared with $57 \%$ for company plans and $74 \%$ for industry-wide plans. These figures may be lower because they use different definitions, but it may also be that larger accounts are less likely to be in the default fund.

${ }^{54}$ APRA: Highlights from 10 years of superannuation data - 1996-2006 excludes plans with assets below €60 million.

${ }^{55}$ Assumes, on basis of APRA statistics, that all retail plans and few other plans have over 20 funds

${ }^{56}$ IAPF Pension Market Survey 2007.

${ }^{57}$ Data taken from "Dealing with the reluctant investor" Byrne, Harrison \& Blake, Cass Business School 2007, which in turn drew data from the NAPF 2006 survey; except for the first 2 columns and the mean figure for number of funds, which are taken from the Pensions Regulator Governance Survey 2008. This survey would also suggest that only $13 \%$ of plans with fund choice have over 20 funds.

${ }^{58}$ PSCA: $50^{\text {th }}$ annual survey of profit sharing and $401 \mathrm{k}$ plans reflecting 2006 plan experience. 
$5.1 \%$ of Australian plans are entirely directly invested with just $6.1 \%$ of all plan assets directly invested $)^{59}$. This is often where the employer also offers a DB plan. In the UK, default fund investment management appears to be highly concentrated in two firms, arising from their strong position in the UK passive investment market ${ }^{60}$. In the US, $54 \%$ of $401 \mathrm{k}$ assets are invested through mutual funds. ${ }^{61}$

The following types of fund are commonly offered to DC plan members:

- Conservatively invested funds, which can either be 'capital guaranteed' (Australian terminology) using cash money or market deposits or 'stable value' (US terminology) funds that are invested in cash and bonds to minimise market volatility;

- Bond funds that may be either actively or passively managed

- Company stock funds (US only);

- Equity funds which can be either actively or passively managed and included no, some or only foreign equities;

- Balanced funds that tend to have the majority of investment in growth assets (Equities, property and alternative investments) with the balance in bonds;

- Life-styled or target maturity date funds where the investment allocation moves from equities or a balanced portfolio to bonds or cash as the member heads towards a standard retirement date or target date selected by the member; and

- Professionally managed funds where the member has a major role in directing a potentially rapidly changing portfolio. This option is less common, for instance only $30 \%$ of US plans offer it.

- With profits funds, common in the UK, where 70\% of plans offer this option (and probably also common in Ireland) but not elsewhere.

- Property funds, although these are much less common ${ }^{62}$.

There is considerable diversity as to the whether a choice of fund manager is offered. In Australia, for instance, such choice is fairly unusual for industry-wide plans but standard for retail plans (explaining the large variation in the numbers of funds offered), and overall $51 \%$ of plans offer a choice of fund manager. The figures for the UK and US (trust-based) are 64\% and 66\% respectively.

The investment allocation of DC plan default funds in all the countries in the survey is heavily weighted towards equities in UK and Ireland or balanced (including consensus ${ }^{63}$ ) funds in Australia.

\footnotetext{
${ }^{59}$ Plans with direct investment are mostly corporate not industry-wide or retail. Source: APRA statistics for 2007

${ }^{60}$ The report by PensionDCisions (op cit) found that these two firms provided over $70 \%$ of the funds covering some $80 \%$ of the plan membership in the survey.

${ }^{61}$ Investment Company Institute: the US retirement market 2007, published July 2008

${ }^{62}$ Only $0.5 \%$ of US DC plan assets are invested such funds. Source: PCSA: $50^{\text {th }}$ annual survey of profit sharing and $401 k$ plans reflecting 2006 plan experience. This is also the main source for the US data that follows.
} 
Uniquely, many of the Australian plans without fund choice offer funds that are smoothed against major shocks in asset values, and some default funds are also smoothed. One source of information suggests that $44 \%$ of US default funds are invested in cash and bonds but this may be out-dated. In any event, data on auto-enrolment default funds suggests that only $17-25 \%$ are invested in that way, with life-style and target retirement funds comprising well over half these defaults ${ }^{64}$, and likely to become even more prevalent in the near future (see above). Equity default funds are virtually unknown.

The UK approach to life-styling a default funds is to aim to hold $25 \%$ cash and $75 \%$ bonds at retirement to replicate the $25 \%$ cash free lump sum and $75 \%$ annuity commonly chosen. Life-styling starts at between five and 10 years before retirement depending on the fund. (Target-date funds which are more common in the US work on a similar basis but with a whole fund being targeted at a date and managed to reduce risk rather than individual accounts switching). From 2012, the default funds of plans that can be used as an alternative to the new personal account must be life-styled. Detailed information on the assets held by all funds in DC plans is summarised in Figure 6 below (more detail in Table 6 in Appendix 2)..

Figure 6: key characteristics of fund investment

\begin{tabular}{|c|c|c|c|c|c|c|}
\hline & \multicolumn{5}{|c|}{ Default Fund } & \multirow{2}{*}{$\begin{array}{l}\text { Overall } \\
\text { Equity } \\
\text { holding }\end{array}$} \\
\hline & $\begin{array}{l}\% \text { of } \\
\text { members }\end{array}$ & $\begin{array}{l}\text { Equity } \\
(\%)^{65}\end{array}$ & $\begin{array}{l}\text { Cash/ bonds } \\
(\%)\end{array}$ & $\begin{array}{l}\text { Investment } \\
\text { style }\end{array}$ & $\begin{array}{l}\text { Life- } \\
\text { styling }\end{array}$ & \\
\hline Australia: & $80-90$ & 55 & 26 & & & \\
\hline $\begin{array}{l}\text { Industry-wide } \\
\text { and company }\end{array}$ & & $59-63$ & 16 & active & No & $\mathrm{n} / \mathrm{a}$ \\
\hline retail & & 46 & 42 & active & No & $n / a$ \\
\hline Ireland & $\mathrm{n} / \mathrm{a}$ & & & & & \\
\hline Trust-based & & $65-80$ & $15-30$ & passive & Few & $66^{66}$ \\
\hline PRSA & & \multicolumn{2}{|c|}{ Similar to above } & passive & All & $\mathrm{n} / \mathrm{a}$ \\
\hline UK & & & & & & \\
\hline Trust-based & $79-88$ & 100 & 0 & passive & Most & $\mathrm{n} / \mathrm{a}$ \\
\hline Contract-based & $\begin{array}{ll}\text { Similar } & \text { to } \\
\text { trust-based }\end{array}$ & $70-80$ & $20-30$ & active & All & $\mathrm{n} / \mathrm{a}$ \\
\hline USA & & & & & & 67 \\
\hline $\begin{array}{l}\text { Auto-enrolment } \\
\text { default funds }\end{array}$ & Around $25^{67}$ & "balanced" & & $n / a$ & $\begin{array}{l}\text { Just over } \\
\text { half }\end{array}$ & \\
\hline $\begin{array}{lr}\text { Typical } & \text { plan } \\
\text { holdings } & \text { in } \\
\text { funds } & \\
\end{array}$ & & $56^{68}$ & 18 & active & $9 \%$ & \\
\hline
\end{tabular}

${ }^{63}$ Consensus funds (which are also popular in Ireland) seek to balance the asset allocation to that offered by the average fund manager, as well as linking the portfolio allocation within each asset class to the market composition.

${ }^{64}$ PSCA: $50^{\text {th }}$ annual survey of profit sharing and $401 \mathrm{k}$ plans reflecting 2006 plan experience.

${ }^{65}$ The asset allocations shown are those applying prior to any life-styling cutting in.

${ }^{66}$ This is the figure for all trust-based plans, that is including DB, but there is no evidence that practice varies between DB and DC.

${ }^{67}$ Over $30 \%$ of members of plans with 200 or more members (and over $40 \%$ of plans with over 5,000 members) operate auto-enrolment. Given experience elsewhere it would be reasonable to assume that at least $80 \%$ of members are in the default fund, which would suggest that at least $25 \%$ of members are now in default funds in auto-enrolment plans. This would be inconsistent with the relatively low plan holdings of lifestyled funds, unless auto-enrolled account balances are well below average in size. It would, however, suggest that most members with life-styled funds are in default funds.

${ }^{68}$ Including 5\% in company stock. 
Some notable features in the data are:

- In Australia, default funds tend to be balanced funds but the holding of growth assets is much lower for retail plans than for others. There is some competition between plans that seek to keep costs low by using passive investment rather than the more common practice of using active investment.

- In Ireland, life-styling of the PRSA fund is virtually universal (presumably to meet the regulatory actuarial prudence requirement) but life-styling of trust-based funds is not, although the option is increasing in popularity.

- In the UK, trust-based default funds are predominantly passively managed equity funds, with the balance being largely passively managed balanced funds. For stakeholder plans the balance shifts to actively managed balanced funds (70-80\% equities) with the rest being passively managed equity funds or (a few) actively managed with-profits funds. Life-styling predominates for all equity-exposed funds.

- In the US, plans are around $67 \%$ invested in equities including company stock. Many members spread their investments across a range of funds, with just over $50 \%$ of plan assets held in equity funds (predominantly domestic and actively managed) with a further equity component from company stock funds $(18 \%)$. This last class of funds is particularly common only in plans with 5,000 or more members. Most of the balance of fund holdings is in bond, cash or 'stable value $^{69}$ funds, with just $8 \%$ and $9 \%$ respectively in balanced and lifestyle-type funds (including target date). But, around half $401 \mathrm{k}$ members hold less than half their portfolio in equities, although $29 \%$ are $100 \%$ invested in equities. These figures also hold good for individual retirement accounts. Life-styled funds are very common for auto-enrolment default funds and, it can be inferred, rare for other types of members.

In summary, while heavy investment in equities is a common feature, there are some important differences:

- Passive management is preferred in the UK and Ireland while active management is preferred in Australia and the US. This may reflect different preoccupations among fiduciaries and members;

- As might be expected, the larger the country, the higher proportion of investment in domestic rather than international equities.

- Balanced (including consensus) funds predominate in Australia and Ireland but are much less common in the UK and the US. This does not, however, appear to have a major impact on the overall allocation to equities.

- Life-styling, which dominates the UK and Irish contract-based markets, is just taking off more generally in Ireland, and the in the US but is scarcely found in Australia. There would appear to have been some trade-off between using balanced funds and life-styling although this relationship is diminishing.

\footnotetext{
${ }^{69}$ Stable value funds hold predominantly cash and bonds, but with some equities, and are managed so as to target a particular level of investment return. They often guarantee the principal and, in the form of guaranteed income contracts, provide some guaranteed return. They lie between bond funds and balanced funds on the spectrum of conservatism.
} 
- Investment in conservative fund choices is unusual everywhere except the US (where fiduciary risk is assumed to have had a strong influence).

\section{Investment performance}

There is considerable aggregate data available on DC investment returns in Australia - much less elsewhere. The value of the data has in any case been somewhat reduced by the recent turmoil in financial markets.

Australian data shows annualised net growth over the decade to 2006, of $6.5 \%$. The performance of different types of superannuation plan varied significantly. For a company plan the figure was $7.6 \%$ compared with $6.5 \%$ for an industry-wide plan and $5.3 \%$ for a retail fund. ${ }^{70}$ As the average rate of inflation during this period was $2.6 \%{ }^{71}$, these figures equate to real net returns of around $3.9 \%$ across all plans, falling to $2.5 \%$ for retail plans. As would be expected from their more conservative asset allocation, returns from retirement savings accounts are lower, with net returns (including guaranteed returns) in the range $3-4 \%$ (nominal) for balances of $€ 3,000-60,000^{72}$.

One reason for the differences between types of superannuation plan appears to be the different level of fees (see section 5). Another reason appears to be investment allocation, with the investments of company plans being more volatile than industry-wide plans which are in turn more volatile than retail plans. Using APRA's index of volatility over the period, the respective figures are 6.6, 6.2 and 5.5. This reflects the higher allocations to growth assets. While there appears to be little systematic relationship between returns and plan size, larger account balances average higher returns and have higher volatility, suggesting that a higher allocation to growth assets, and possibly a lower allocation to the default fund, provides the explanation.

While there are significant differences between returns for individual plans over shorter periods, over the 10 year period the lower quartile is just $0.9 \%$ below the upper quartile for company plans, $0.4 \%$ below for industry-wide plans and virtually identical for retail plans. APRA's box plots show wider variations, and indeed the core box within which most plans fall, is for company plans entirely above that for industry-wide plans, which is mostly above that for retail plans. Hence plan type has a much bigger effect on performance than individual plan behaviour.

A small UK survey of default funds ${ }^{73}$ shows that net annualised performance over the three years to December 2007 was $14.2 \%$ for equity funds, $13.1 \%$ for balanced funds and $5.9 \%$ for bond/cash funds. The net performance of passive equity funds was on average $0.8 \%$ better than that for active funds over the last five years. There is some variation between passive equity fund performance reflecting in particular the different UK/global asset mix. These figures would need to be adjusted by annualised inflation during the period of around $2.5 \%$ to give real returns.

\footnotetext{
70 APRA: Highlights from 10 years of superannuation data - 1996-2006. Figures to July 2006 calculated after expenses and taxes. The overall figure includes public sector plans and excludes plans with less than $€ 60$ million of assets.

${ }^{71}$ Reserve Bank of Australia Inflation Calculator (intended as a guide only).

${ }^{72}$ Example taken from Savings \& Loans Credit Union website for June 2007.

${ }^{73}$ PensionDCisions: Default strategies in context
} 
US data ${ }^{74}$ shows annualised median net investment returns of $401 \mathrm{k}$ plans of $6.8 \%$ over the decade to the end of 2006, compared with $7.3 \%$ for the DB plans. When the figures were weighted by plan (asset) size the comparative figures became $7.6 \%$ and $8.8 \%$, indicating that DC plans seem less able to benefit from scale than DB plans. Bigger plans out-performed smaller plans by around $0.7 \%$. As inflation averaged $2.3 \%$ during this period ${ }^{75}$, the real rate of return for $401 \mathrm{k}$ plans was $4.5 \%$. This figure is higher than the overall average for Australia (3.9\% above), which may reflect, in part, the higher equity allocation, but is lower for the figure for Australian company plans which may reflect the impact of fees.

The only overall conclusion to be drawn is that net performance is affected by fee levels and that a higher equity component results in higher returns and higher volatility. It should be noted, that comparisons between balanced funds are difficult unless allowance is made for the differences in the allocation to growth assets. These show up in the differences found between Australian plans, and between them and US plans. Evidence shows that the term 'balanced fund' in the UK can cover a marked difference in the allocation to growth assets - a UK survey showed variations between $73 \%$ and $86 \%{ }^{76}$.

\section{Fund allocation during the payout phase}

This is covered in section 6 below.

\section{Conclusions}

The following conclusions can be drawn:

- Most plans use third parties to provide the funds in which member balances are invested, and investment in unitised products is very common.

- Most plans offer members a choice of fund with contract-based plans offering considerably more funds than trust-based. Outside the US, at least, plans with fund choice usually offer a default fund even where this is not required (although it is increasingly becoming one). It appears that the most common US practice is for members to spread investments across funds.

- The majority of members in each country, including those in default funds, are at least $70 \%$ invested in growth investments, primarily equities. This is because commonly used balanced or consensus funds include that level of growth assets. But significant minorities of members hold conservative (mainly in the USA) or all-equity (especially in the UK) portfolios.

- Consequently, most members achieve strong returns most years that are subject to considerable volatility. Net returns appear higher for larger plans and trust-based plans, reflecting differences in asset allocation and fee levels.

- There is some evidence (primarily in Australia) that commercially provided plans have a more conservative approach to default fund investment than trust-based plans, and therefore achieve lower long term rates of return.

\footnotetext{
${ }^{74}$ Watson Wyatt insider: Defined Benefit vs. 401(k) Plans: Investment Returns for 2003-2006 - based on returns to the Department of Labor analysed by the Boston Center for Retirement Research. The data has been weighted by the assets in each plan better to reflect member experience. The comparison between big and small plans relates only those to those whose sponsors also had a DB plan.

${ }^{75}$ Department of Labor statistics.

${ }^{76}$ The Reluctant Investor (page 34) op cit
} 
- The USA differs from the other countries in the much lower (although growing) use of default funds, which probably explains the greater prevalence there of conservatively invested funds.

- The general preference for active fund management found in Australia and the USA is not found in Ireland and the UK, where (lower cost) passive investment strategies are most common.

- Life-styled default funds are the norm in the UK and for Irish contract-based plans, are becoming more common in the USA, but have yet to become significant for Australia plans, US plans without auto-enrolment or Irish trust-based plans.

\section{Fees}

\section{The regulation of fee structures and levels}

The countries surveyed only regulate the size and nature of fees in relation to specific types of product, as follows:

- In Australia fees and charges applied to pension plans (including approved deposit funds and retirement savings accounts) holding less than $€ 610$ may not exceed the investment returns to those accounts.

- Ireland and the UK have set maximum charges for the regulated default products, that is standard PRSAs and stakeholder pensions respectively. The charge for standard PRSAs is capped at $5 \%$ of contributions and $1 \%$ of assets ${ }^{77}$. The charge cap for stakeholder pensions is currently $1.5 \%$ on assets for the first 10 years and $1 \%$ thereafter $^{78}$. It should be noted, however, that only a relatively small; proportion of employees contribute to these products, especially in Ireland where under $2 \%$ of funds under pension assets are held by PRSAs.

There is also some limited regulation of fee structures:

- the regulation of fees for PRSAs and stakeholder pensions requires that no charges can be made for transfers of assets or the suspension and resumption of contributions. Proposals to alter charges must be notified to contributors.

- The regulations covering US safe-harbor plans similarly prohibit charges for transfers. More generally, for participant choice to absolve the sponsor from fiduciary liability, the transaction fees must not be set so high as to discourage choice.

Apart from these requirements, fee levels are unregulated with the focus instead being on disclosure (see below) or in the US through the duty that ERISA in the US applies to fiduciaries that they must, among other things "ensure that fees paid to service providers and other expenses of the plan are reasonable in light of the level and quality of services provided".

\footnotetext{
${ }^{77}$ Non standard PRSAs also exist on which there is no charge cap - but these are not the default provision.

${ }^{78}$ For stakeholder pensions sold before 6 April 2005 the cap is $1 \%$ for the duration of the contract.
} 
Where the employer covers administrative costs there is a risk that charges may instead have to be levied on member balances where the employer becomes insolvent ${ }^{79}$. Australian superannuation plans may reserve for situations where the fees and charges prove insufficient to cover costs putting plan solvency at risk, as part of their risk management process. The general assumption regarding contractbased plans (in Ireland and the UK) is that the commercial provider will bear any losses incurred due to the charge cap, and indeed providers in the UK and Ireland have alleged that the cap has constrained their activity in this market.

\section{Disclosure of fees and charges}

Regulation can influence the fees charged through disclosure requirements that may facilitate 'shopping around' by employers, and employees where they have a choice. Disclosure requirements are set out in Table 7 in Appendix 2. In summary, there is considerable transparency of fees in Australia, and for stakeholder/ PRSA products in the UK and Ireland. There is much less for trust-based plans in the UK, Ireland and the US. This means that members cannot usually see what investment management charges have been levied against their accounts, nor indeed what administrative charges have been levied for the minority of US plans where these charges are levied against the plan. In no country is there is a requirement to disclose explicitly the costs of fund management arising from financial market transactions, such as bid-offer spreads.

One interesting form of disclosure is found in the UK where independent financial advisers selling personal pensions are required, in disclosing the fees payable, to tell customers what they would incur if they bought a stakeholder product instead ${ }^{80}$. This rule is considered to have helped push down charges on personal pensions to levels broadly comparable with stakeholder pensions. It may be of less relevance to employer sponsored pensions which commonly do not involve regulated financial advice and where economies of scale have tended to keep contract-based pension fees below the stakeholder charge cap.

\section{Fee levels in practice}

The level of fees charged can have a large impact on net returns - some estimates show a fee of $1 \%$ of the asset value reducing average net returns by nearly $20 \%$.

Data is sketchy on the level of fees charged for non fee-regulated products. Furthermore, the data that does exist covers explicit charges relating to sales and management, not the implicit charges arising from trading securities which are netted off within figures for investment returns. The UK Pensions Commission, drawing on a 2000 paper from the Financial Services Authority, estimated that UK trading costs could reduce yields by over $1 \%$ for an actively managed fund and nearly $0.8 \%$ for a passively managed fund. ${ }^{81}$ Yield reductions for US funds were lower. This effect will show up in data on net returns but not necessarily in the data on fees and charges.

Table 8 sets out the available data on explicit charges borne by DC plans and their members. In summary:

\footnotetext{
${ }^{79}$ The UK Pension Protection Fund only provides compensation to 'pure' DC plans in the event of fraud. The Irish fraud compensation fund similarly only covers against fraud and there is no equivalent of the PBGC or PPF.

${ }^{80}$ The Financial Service Authority's RU64 rule

${ }^{81}$ The first report of the Pensions Commission: Pensions challenges and choices published in 2004
} 
- While most types of plans are free to charge a range of different types of fees to members, the annual management charge predominates (except possibly in the US).

- Administrative costs are not generally passed through to members of Irish and UK trust-based plans and are passed through to varying degrees for US plans. Available figures suggest that are in the range of $0.2-0.4 \%$ of account balances except for public offer plans in Australia where they average $0.5-0.6 \%$.

- Investment management costs are, however, the largest cost element, not generally reimbursed by employers and vary considerably. For UK trust-based plans, they average around $0.2 \%$ and $0.5 \%$ for passively and actively managed funds respectively, but size of plan has an impact. Australian figures are in the range $0.25-0.45 \%$, probably reflecting a greater prevalence of active fund management, which suggests that the additional cost of active fund management is in the range of $0.2-0.3 \%$. The mutual funds, in which US plans invest heavily have charges around $0.7 \%$.

- Taken together, this evidence suggests that the costs of trust-based plans are $0.4-0.9 \%$ in the UK, $0.67-0.93 \%$ in Australia and upwards of $1 \%$ in the USA. The higher Australian costs may be explained by the costs of public offer provision and active fund management (especially as company plans have the lowest costs).

- Turning to the fees actually charged by plans where the employer does not bear a large part of them, the average charges of the cheaper (presumably passively managed) funds offered by nonretail Australian public offer plans tend to be similar to or slightly higher than the figures for UK contract-based plans of around $0.8 \%$ of assets. Doubtless therefore marketing and sales costs explain much of the difference, along with profits for a commercial provider, which may explain why retail plan fees are 50-100\% higher than industry-wide plan fees.

- Fees appear to be higher for contract-based plans in Ireland, with no evidence of fees below the regulatory charge cap (equivalent to $1.2 \%$ ).

- Fees are still higher for most of the funds offered by Australian retail plans, which have median fees of $1.8 \%$, explained in part presumably by the active management component.

- Fees are said to be 1-2\% in the US, which may reflect the lack of transparency and the prevalence of actively managed funds. They are also significantly higher for many funds offered by Australian retail plans, (1.8\% for the median retail fund)

\section{Conclusions}

While there is a wide range of fee structures, most of the fees charged are levied as an annual management charge. Fee levels are unregulated for most plans covered by this survey, with effective regulation of transparency limited to Australia and specified products in Ireland and the UK. In practice, the only fees applied to member balances in trust-based plans in Ireland and the UK are relatively small investment management fees, as employers bear administrative costs. Employers also bear some or all administrative costs of many US plans.

There is evidence that active fund management costs members significantly more than passive, with the UK figure of a $0.3 \%$ premium providing a guide to the amount it adds to the $0.4-0.6 \%$ basic cost of trust-based plans. Having a commercial provider has the biggest impact on fees borne by members, with 
average fees for contract-based and retail plans being significantly higher than trust-based counterparts in Australia, Ireland and the UK.

The regulation of stakeholder pension fee levels in the UK appears to have little direct impact, as the general level of fees levied on workplace pension plan members in the market is well below the cap, but they may well have kept UK group personal pension fees down. The Australian approach of making fee disclosure transparent appears to have had limited effect with retail funds having charges of around $1.8 \%$ around double those in company and industry-wide plans, or indeed for contract-based plans in the UK. Some of this disparity may relate to the prevalence of actively managed funds, but even the lower quartile fund charge is still $1.05 \%$.

In Ireland, the PRSA charge cap does appear to drive the market, resulting in a higher fee level equivalent to $1.2 \%$ of balance, presumably because there are few if any large employer-sponsored PRSA plans. The absence of regulation of fee levels or, effectively, of transparency in the USA appears to be associated with higher levels of fees being charged, over 1\%, than for any but Australian retail plans, despite the duty placed on fiduciaries to keep fees reasonable.

\section{Payout rules}

\section{Payout prior to retirement}

Before considering payout rules at retirement, it is worth briefly focusing on the latitude that may exist to cash-out account balances before retirement. The guiding principle in Australia, Ireland and the UK is that DC balances should be either retained in the plan, or transferred to another plan from the vesting date through to the plan retirement date ${ }^{82}$. There are strict restrictions on withdrawal from the pension system before the retirement date with heavy tax penalties on any withdrawals that are allowed by plan rules. This is the case also for money purchase plans in the US.

In Australia and the US, withdrawals may be allowed in specified cases of hardship, subject to tax penalties $^{83}$. In the US, the definition of hardship is fairly wide as some $85 \%$ of $401 \mathrm{k}$ plans include purchase of primary residence and payment of medical expenses within the definition ${ }^{84}$ The Australian definitions appear tighter and some forms of withdrawal must be approved by the supervisor. In the US, statistics suggest that in 2007 around $1.5 \%$ of members took a hardship withdrawal, with an increasing trend in such withdrawals (up $28 \%$ since 2005). ${ }^{85}$

Alone of the countries surveyed, US 401k and profit sharing plans allow members to take out loans from their accumulated entitlement if this is permitted by the plan rules (as it is in at least $85 \%$ of the

\footnotetext{
${ }^{82}$ All benefits are vested after 2 years plan membership in the UK and Ireland, but UK members can require their balance to be transferred to another plan after 3 months. In Australia, employee contributions made after 30 June 1999 and employer contributions mandated by the law or a collective agreement are vested immediately.

${ }^{83}$ In the US there is a $10 \%$ tax penalty on top off routine income tax on the amount.

${ }^{84}$ PSCA: $50^{\text {th }}$ annual survey of profit sharing and $401 \mathrm{k}$ plans reflecting 2006 plan experience. The percentages are much lower for profit sharing plans as only $33 \%$ of these allow hardship withdrawals.

${ }^{85}$ Source: Vanguard Center for Retirement Research
} 
$401 \mathrm{k}$ plans and $29 \%$ of profit sharing plans). Some $19 \%$ of those members eligible for this facility had loans outstanding in $2005^{86}$.

In the US, where employees change jobs and have a balance under $€ 3,250$ the employer can transfer the balance out of the scheme. The default destination is now required to be an individual retirement account (until fairly recently the default could have been cash), but the new employer's 401k plan would be another option where the plan accepts roll-overs from other plans ${ }^{87}$. Members may, however, cash these balances out (incurring a tax charge of $20-50 \%{ }^{88}$ ) when they change jobs. Cashing out is still the norm for balances under $€ 650$ while employees are free to retain the balance in the original $401 \mathrm{k}$ plan for balances over $€ 3,250$.

Statistics show that $20 \%$ of the 7.5 million members leaving a 401k plan in 2004 (including the $16.7 \%$ who were retiring) cashed out, meaning that many cashed out despite staying in the workforce ${ }^{89}$. These figures are also interesting as it suggests that nearly $20 \%$ of $401 \mathrm{k}$ members withdraw from their plans each year because they have changed jobs - five times the number who retire. Other research ${ }^{90}$ suggests that the cashing-out proportion was $45 \%$.

\section{Retirement ages}

The statutory minimum retirement date at which routine withdrawal of vested benefits from the pension system is allowed without tax penalty is 50 in Ireland and the $\mathrm{UK}^{91}, 55$ rising to 60 in Australia ${ }^{92}$ and 591/2.in the USA ${ }^{93}$. In Ireland and the UK the normal retirement age specified in trust-based plans in 65, while the PRSA retirement age is 60 and the UK stakeholder age is the same as the statutory minimum (currently 50). All four countries allow employees to continue to work and contribute to their pension plan beyond the normal retirement age so long as plan rules permit it, although the US requires members to start taking their benefits from age $70 \frac{1}{2}$, at which point one of the various payout options must be applied.

\section{Regulated options at retirement}

The regulated options are detailed in Table 9 in Appendix 2. In summary, the countries in the survey vary between those that require most of the balance to be taken as an annuity or regulated drawdown product and those that give members considerable freedom:

${ }^{86}$ EBSA statistics - the $50^{\text {th }}$ annual survey of profit sharing and $401 \mathrm{k}$ plans gives a higher figure of participants with loans $23.7 \%$ which covers both types of plan, as well as providing the statistics for profit sharing plans allowing loans.

${ }^{87}$ While over $98 \%$ of $401 \mathrm{k}$ plans accept roll-overs, only $55 \%$ of pure profit sharing plans do. (Source: PSCA $50^{\text {th }}$ annual survey of profit sharing and $401 \mathrm{k}$ plans.

${ }^{88}$ There is a $20 \%$ tax penalty applied to the plan administrator and the member then probably has to pay $10 \%$ on top, there is a further tax penalty if the member is aged under 55. And then the member must pay federal tax on the remaining income.

${ }^{89}$ According to Brightwork Partners research. Of the 7.5 million, 6.25 million were job changers and 1.25 million retired. Of the 7.5 million, $55 \%$ had $401(\mathrm{k})$ balances greater than $\$ 5,000$.

${ }^{90}$ Hewitt Associates

${ }^{91}$ Rising to 55 from 2010 in the UK

${ }^{92}$ The age is 55 for those born before 1 July 1960, 60 for those borne after 30 June 1964, with a sliding scale for those born between those dates.

${ }^{93}$ But only if allowed by plan rules, or at the discretion of the trustees) 
- In the UK and Ireland most plan balances have to be liquidated at retirement (the exception being PRSA balances that can be kept open until age 75). Regulation provides for tax-free cash up to $25 \%$ for UK and Irish contract-based plans, with a fairly comparable salary-related limit for trust-based plans in Ireland. The remainder, where it exceeds a specified (trivial commutation) minimum has either to be used to buy a life annuity or a regulated income drawdown product. The latter is limited to some types of member in Ireland, in particular PRSA holders, where a minimum drawdown of 3\% a year is being phased in. Only these classes of Irish members may also take taxable cash and then only if they have pensions from other sources above a (large) specified size.

- In Australia and the US, subject to plan rules, members may take the balance as cash (taxable in the US, tax-free in Australia after age 60), an annuity or a rollover into the same or a different pension product. Where retained in a pension account it has to be drawn down according to minimum levels specified by tax regulations - in particular drawdown must start at $701 / 2$, in the US. In both countries there are tax advantages to retaining money in the pension plan rather than investing it elsewhere (because of the tax charge on release in the USA and because pension investment income and payments are tax-free in Australia).

None of the countries in the survey place any restrictions on the type of annuity purchased, except that in Ireland and the UK it has to be for the whole remaining life of the annuitant(s). Hence, single life, joint life, escalating (inflation-linked), variable and with profits annuities are all allowed and marketed. Providers also offer guarantees of some return in the event of the annuitant's death during the first few (commonly five) years of the contract, effectively introducing an element of life assurance. In Australia and the US retirees can also take out fixed term annuities.

\section{Choices at retirement in practice}

There is a great contrast in this survey between the UK and Ireland on the one hand, where it is usual for retirees to take the maximum amount of tax-free cash and buy an annuity with the balance, and Australia and the USA where annuity purchase is fairly unusual. Instead the common practice is to keep the money in a regulated pension product, often the same pension plan, with a substantial proportion simply taking the cash (for spending or non-pension saving). In particular:

- In Australia, research from 2000 indicated that at least $90 \%$ of the plan benefits of private sector members were taken as lump sums, with the major part of the remainder being used to buy income drawdown products (then "allocated" now "account-based" annuities) and only a small proportion buying conventional annuities, of which fixed term predominated over life. ${ }^{94}$ Since then income drawdown products appear to have increased in popularity, often offered by the member's plan as an alternative to enabling draw-down at will from the pension plan. As at least $10 \%$ of pension plan assets now relate to members at or over age 65 , it can be inferred that a substantial proportion of members draw down in a planned manner or at will from a pension plan representing a significant shift since 2000 . Life annuities remain very unpopular.

- In the US, over $99 \%$ of profit sharing and $401 \mathrm{k}$ plans offer lump sums, $37 \%$ income drawdown and only $15 \%$ annuities. $74 \%$ allow participants to retain balances in excess of $€ 3,200$ in the plan and $26 \%$ of plans allow them to retain smaller balances ${ }^{95}$. The extent of choice tends to

\footnotetext{
94 Source: the World Bank, Policy Research Working Paper 2495 "The Australian Annuity Market", David M Knox

${ }^{95}$ All these figures are drawn from the PCSA's $50^{\text {th }}$ annual survey of profit sharing and 401k plans, covering 2006.
} 
increase with plan size ${ }^{96} .2004$ statistics showed that $6 \%$ of members leaving a $401 \mathrm{k}$ plan bought an annuity or income drawdown product. As $16.7 \%$ of the members were retiring and it is presumably unusual for the pre-retired to buy such a product, this suggests that around a third of retiring DC plan members buy an annuity or income drawdown product. It seems likely that most of the remainder rolled the balance over into an individual retirement account (IRA), with some taking taxable cash. This provides one explanation for the very large balances held in IRAs.

Because the UK has only recently liberalised the rules covering income drawdown arrangements, few statistics are available on their prevalence, although anecdotally it is understood that most retirees still annuitise. Income drawdown products are in any case marketed at retirees with large balances who are prepared to take independent advice and make their own fund choice. Ireland has had income drawdown through Approved Retirement Funds and Approved Minimum Retirement Funds (ARFs and AMRFs) for longer and there is some evidence that they may now be more common than annuities, at least for members with a choice, with 57\% more ARF policies than annuity policies issued in 2004. They are more attractive to retirees with larger balances with the average ARF balance in 2004 being $€ 150,000$ compared with the average life annuity balance of $€ 82,000^{97}$.

\section{Characteristics of the main payout products (including fund allocation)}

\section{Life annuities}

Nearly all DC retirees in the UK and a large proportion in Ireland purchase annuities. In Australia and the US only around a small proportion of retiring members purchase a life annuity. What follows therefore focuses particularly on the UK and Ireland.

Despite the wide choice of annuity types, in practice most UK retirees buy a simple fixed level annuity - while some $90 \%$ of annuities purchased in Ireland are fixed level or fixed increase annuities ${ }^{98}$.

The investment of the funds used to pay annuities is not of direct concern for retirees, as the pension payments are contractually guaranteed, with the provider bearing investment and longevity risk, and subject to prudential regulation and supervision. In practice, the investment approach adopt by the annuity providers is very conservative reflecting the risks to the provider and the regulatory environment, with a focus on duration-matched bonds giving annual returns of 4-5\% (nominal). Higher returns can potentially be achieved if the retiree buys an investment-linked annuity (with-profits, variable or unit-linked) where

\footnotetext{
${ }^{96}$ Hence , for plans with 5,000 or more members, $48 \%$ offer income drawdown, $16 \%$ annuities, and $81 \%$ retention of larger balances.

${ }^{97}$ Source: National Pensions Review (2005), appendix 5 - report by Hewitt Associates on "Benefit Options at Retirement". The figures for average premiums look remarkably high and the figures for total policies (around 3,000 a year) rather low, which suggests that the figures may just cover the higher end of the market. The balance certainly looks odd bearing in mind that members of trust-based plans cannot use ARFs. On the other hand Hewitts note that the figures exclude ARFs opened through stockbrokers which may result in the number and average size of ARFs being under-stated. The balance between ARF and life annuity premiums was even more skewed towards the former in 2003. Hewitts' figures came from an unpublished Irish Insurance Federation source.
}

${ }^{98}$ For UK as stated by DWP Research Paper 318, for Ireland as in Chapter 11 of the Pensions Green Paper. 
an element of the fund is invested for higher returns leaving a smaller guaranteed income ${ }^{99}$. It was said in 2006 that these types of annuity are not widely available in Ireland. ${ }^{100}$

Because Irish and UK regulation effectively requires most retirees to buy an annuity, many plans have sought to protect members by offering members an 'open-market' option at retirement, i.e. a choice of annuity provider. Plans are legally required to offer this option in the UK, and it is understood that most plans offer an open market option in Ireland (but there are no statistics). If this choice is not exercised the plan will buy the member an annuity from a default provider. This may give poorer value for money, especially for members of a contract-based plan where the default will be the provider's own annuity regardless of its competitiveness. In reality, however, only $33 \%$ of retiring members in the UK exercise the open market option (and the figure in Ireland is likely to be lower) ${ }^{101}$. With minimum purchase prices on external annuities ranging upwards from $€ 6,300$, the open market option may be out of reach for the $23 \%$ of UK retirees with a balance at retirement of less than $€ 6,300$ and the $41 \%$ with balances less than $€ 12,600$

There is some debate about the extent to which members are disadvantaged by failing exercise the open market option. Research in 2008 covering 26 annuity providers, found that $85 \%$ of single life level annuity customers receive a rate that is at least $95 \%$ of the highest rate available ${ }^{102}$. The research found that those with a pension pot of $€ 12,600$ stand to gain $€ 670$ over the life of an annuity by exercising the open market option - savings which could easily be swallowed up by adviser fees. That said, quotes online in May 2008 showed the worst available offer being 11\% less than the best. Furthermore, the position is likely to be less favourable for other types of annuity, notably impaired life annuities which will not be the default, or including annuity providers not active in the market place.

The major risk to members purchasing annuities, however, has been the decline in the size of pension that can be bought, as annuity rates have fallen due to reduced long term interest rates and increasing longevity. A person who retired in 1991 with a fund of $€ 100,000$ would have been able to purchase a flat-rate single life pension of $€ 12,000$ per annum on the open market. However, a 65 -year-old retiring in 2006 would have needed a retirement fund of approximately $€ 180,000$ to purchase the same pension $^{103}$.

\section{Income drawdown}

Income drawdown products are available to retirees in all the countries covered by this survey, although they are subject to regulatory restrictions in the UK and, more so, Ireland ${ }^{104}$. The range of types

${ }^{99}$ Variable annuities are effectively unit-linked annuities with more optional features. Strictly speaking there is no guaranteed income for unit-linked annuities, but as some investment units are sold each payout period there will be some income unless their value drops to zero. But the amount of this income will not be predictable.

100 Source: "Annuities still the best choice for many", Peter Hanrahan published in Ireland's Business Review (BNET United Kingdon). This is the source for the anecdotal information relating to Ireland in this section of the paper. The statement probably still holds good as retirees with higher balances who wish to run some investment risk are more likely, where they can, to use income drawdown

${ }^{101}$ No figures are available for Ireland

${ }^{102}$ Research by the Association of British Insurers

${ }^{103}$ These are figures for Ireland but UK figures would be similar. Currently $€ 100,000$ would purchase an annuity of $€ 7,760$ a year (single-life aged 65 , no special features or impairment)

${ }^{104}$ The main restriction in the UK, where the retiree is under 75, is that the annual income may not exceed $120 \%$ of the income that Government Actuaries Department (GAD) estimate that a level single-life annuity would 
of product is limited only by the imagination of those designing them, so any generalisations about detailed product design are problematic. The essential feature is that the fund is invested to make a return with an arrangement pay out guaranteed or variable amounts each year. They are subject to ongoing administration and investment management charges (unlike annuities where charges are bundled into the rate agreed when the annuity is purchased). The product can commonly be converted to a life annuity (or a taxable lump sum in Australia and the US) at the retiree's discretion, although termination penalties may apply.

While a common concern about income drawdown is that retirees, given a chance, may rapidly run down their pension savings before thy die, what evidence there is suggests that in practice retirees tend to be more circumspect. An Irish insurer has advised that in 2004 the average drawdown from its ARF portfolio of over $€ 100$ million was around $7 \%$, which at that date was no greater than the annual annuity payments such a capital sum would support ${ }^{105}$. This observation is supported by the literature relating to income drawdown in the UK and Ireland which emphasises the retiree's ability to bequeath some of the balance.

Reviewing the marketing literature for income drawdown products in the UK suggests that they tend to be actively managed balanced funds, with a similar risk and return profile to pension plan funds of that nature $^{106}$ or with conservative investment of assets to pay the first few years' payments and growth investments for the remainder, which probably produces a similar result. Indeed, it is recognised that retirees who wish to be very conservatively invested would do as well or better to buy an annuity. In any event, retirees are expected to take financial advice and to choose from the provider's standard portfolio of funds. They are often marketed as being suitable only for large balances, say upwards of $€ 125,000$ 250,000 , which would itself indicate that they are not that prevalent.

Stand-alone Australian income drawdown products have similar features of wide investment choice, ongoing charges and flexibility in taking out income (within regulated limits). Australia differs from the other countries in that income drawdown is commonly not a separately regulated product, but a feature provided for retired members of pension plans or approved deposit funds. In these cases, the investment allocation may not necessarily differ from that applying to pre-retired members. Approved Deposit Funds, which have a more conservative investment profile, have shrunk to a very small proportion of the market.

\section{Roll-over into pension plans}

Where pension account balances are rolled over within the plan or into a similar plan for drawdown at will (subject to minimum levels required by legislation), as happens commonly in Australia and the US, the fund is invested in the same way as it was pre-retirement (but see above). Of course, as these accounts are almost universally subject to member investment choice it may be that members change their investment profile at this stage.

Roll-overs in the US are most commonly into individual retirement accounts. The available evidence suggests that the investment allocation of IRAs is similar to that for 401k plans (see Table 6 last few sentences) except that the development of safe-harbor plans has not applied to IRAs. This means that

produce from the capital sum. This amount has to be reviewed every five years and to be adjusted according to the fund value. For over $75 \mathrm{~s}$ the product becomes an 'alternatively secured pension' with minimum and maximum pay-outs of 55\% and $90 \%$ respectively of the GAD figure above.

\footnotetext{
${ }^{105}$ Source as note 92

${ }^{106}$ For instance with an allocation of $75 \%$ to growth assets (Central Wealth Management Ltd).
} 
balances held in retirement could well be subject to the problems that flow from the absence of default funds or provision of conservative defaults.

\section{Conclusions}

The pay-out phase is the aspect of DC provision that varies most across the anglo-saxon tradition, with the main similarity being the tax advantageousness of keeping the larger part of pension accumulations within the pensions system. Prior to retirement there is greater freedom to remove money from the pension system in Australia and especially the USA, notably through the 401k loan facility. The scope for taking early retirement pensions also varies. Three approaches are available to members at retirement:

- Removing the account balance from the pension system totally, capped in Ireland and the UK but not in Australia and the USA where total removal is common. Unless the money is reinvested, losing tax breaks in the process, this would appear to defeat much of the public policy object of providing a reliable income in retirement.

- Continuing the pure DC nature of the plan into retirement by maintaining an investment account with either pre-determined levels of drawdown or drawdown at will, subject to regulated minima. This leaves members exposed to investment and longevity risk but gives them the greatest flexibility in tailoring retirement income to their personal circumstances, assuming they have a large enough balance to justify the ongoing management costs. This is the predominant approach in Australia and the USA.

- Switching to a DB environment through an annuity, which removes longevity risk. It can also be chosen to give some investment risk/return exposure, but most annuitants (in Ireland and the UK at least) choose to remove all investment risk while taking on a greater exposure to inflation risk.

The systems in the countries surveyed result in a substantial differentiation between Australia and the USA where the first two approaches predominate, and Ireland and the UK where the larger part of retirees balances follow the third approach, albeit with increasing use of the second where available or justified by the size of balance. There is a lesser distinction between Australia and the USA, given the greater use in the latter of stand-alone income drawdown and annuity products. More research could be beneficial into which approach is most likely to protect retirees in retirement, although it seems unlikely that allowing members to cash out their full balance at retirement is optimal.

The different approaches have different implications for optimal pre-retirement investment strategies The first and third produce a 'cliff-edge' whereby investment downturns at their retirement date can substantially affect the money available for retirement (especially to the extent that annuitisation is unavoidable). This provides a good explanation for the prevalence of life-styling, as a mitigating strategy, in the UK, and indeed its growth in the USA. The absence of life-styling in Australia can only be rationally explained by assuming that members are intended to move to income drawdown. Common practice in Ireland, where PRSA members are commonly in life-styled funds and can choose income drawdown, but trust-based members have neither facility, is harder to explain. 
APPENDIX 1

\section{TERMS OF REFERENCE: RISK MANAGEMENT IN PENSION FUNDS}

\section{Objective of consultancy}

The main objective of the study is to provide a comparison of DC arrangements in Anglo-Saxon countries, focusing on occupational pension arrangements in Australia, Ireland, the United Kingdom and the United States. The consultant will also provide ongoing support to the OECD's joint project with Allianz, assisting in the identification of data, liaising with consultancy firms, pension funds, and regulatory authorities when relevant.

\section{Components of the consultancy}

The consultant would prepare a 25-30 page report including the following information for the mentioned countries:

- Contribution policy:

- Employer vs. employee financing;

- mandatory or optional;

- depending on salary or fixed

- Investment policy

- Investment regulations, regulated choices and default options

- Actual investments

- Typical allocations during accumulation and payment phase;

- Typical investment options and default options for plan members during the investment phases

- Fees

- Regulations of fee structures and fee levels

- Average fee levels in industry 
- Payout rules

- Regulated options (lump sum, annuity, programmed withdrawals) and defaults;

- Typical benefit option 


\section{APPENDIX 2}

\section{SUPPORTING TABLES}

Table 1: memberships and assets of DB and DC plans in the surveyed countries

\begin{tabular}{|c|c|c|c|c|}
\hline & Australia (2007) & $\begin{array}{ll}\text { Ireland } & (2007 \\
\text { and 2006) } & \end{array}$ & UK $\quad$ (2007) & $\begin{array}{l}\text { USA } \\
(2005)\end{array}$ \\
\hline $\begin{array}{l}\text { Private pension memberships } \\
\text { (millions) }\end{array}$ & & 2007 & & Active \\
\hline DB & $\begin{array}{l}\mathrm{n} / \mathrm{a} \text {, but less than } \\
1.5^{108}\end{array}$ & 0.53 & $\begin{array}{r}14(3.5 \\
\text { contributing })\end{array}$ & 20 \\
\hline DC Trust-based & 27.5 less $\mathrm{DB}^{109}$ & 0.27 & $\begin{array}{r}2.5(1.4 \\
\text { contributing })\end{array}$ & 62 \\
\hline Of which $401 \mathrm{~K}$ (US only) & & & - & 54 \\
\hline Contract-based & $\mathrm{n} / \mathrm{a}$ & 0.045 (PRSA) & $\begin{array}{r}4(2.9 \\
\text { contributing) }\end{array}$ & - \\
\hline Total memberships/millions & 21 & 0.85 & 20.5 & 82 \\
\hline Assets/ €billion & & 2006 & & \\
\hline DB & $\mathrm{n} / \mathrm{a}$ & 71 & 1,000 & 1,450 \\
\hline $\begin{array}{l}\text { DC Trust-based Plans with over } 4 \\
\text { members) }\end{array}$ & 495 & 12 (+4 for AVCs) & 70 & 1,810 \\
\hline Of which $401 \mathrm{~K}$ (US only) & & & & 1,580 \\
\hline DC contract-based & 0.7 & 0.5 & Over 100 & \\
\hline Total assets/ €billion & 496 & 87 & over 1,170 & 3,260 \\
\hline
\end{tabular}

Table 2: limits on contributions to private pension plans

\begin{tabular}{|c|l|}
\hline Australia & $\begin{array}{l}\text { Limit of } € 30,500 \text { a year deductible for tax purposes (except for the taxation applying to the plan } \\
\text { itself) and } € 91,500 \text { undeductible, with some transitional provisions until } 2012 \text { for members aged } \\
50, \text { as caps were reduced from } 2007 .\end{array}$ \\
\hline Ireland & $\begin{array}{l}\text { Limits tax relief on employee contributions to trust-based plans and total contributions to } \\
\text { contract-based plans according to a sliding scale from } 15 \% \text { of salary below age } 30 \text { to } 40 \% \text { of } \\
\text { salary from age } 60\end{array}$ \\
\hline
\end{tabular}

${ }^{107}$ Individuals often belong to multiple plans so that the total number of memberships far exceeds the actual number of participating individuals.

${ }^{108}$ Private sector DB plans have under $0.2 \%$ of assets (and a lower percentage of memberships, but some other plans hold DB as well as DC assets. Figures for these holdings (which probably far exceed holdings in pure DC plans are not available but are unlikely to exceed $2 \%$ of the total.

${ }^{109}$ The memberships exclude a further 2.9 million public sector memberships and are spread across a working population of 10.2 million, implying that each individual has on average three accounts. 


\begin{tabular}{|l|l|}
\hline UK & $\begin{array}{l}\text { Limits tax relief on contributions to the lesser of } 100 \% \text { of salary and } € 285,000 \text {. Also applies a } \\
\text { maximum to individuals' tax relievable total pension savings, (as does Ireland). }\end{array}$ \\
\hline USA & $\begin{array}{l}\text { In simple terms, a limit of around } € 29,000 \text {, of which employees may contribute no more than } \\
€ 9,700 \text { plus up to } € 3,230 \text { a year 'catch-up' amounts for employees aged } 50 \text { or over (2006 } \\
\text { figures). These limits are indexed for inflation. (The rules are more complex than this). For } \\
\text { SIMPLE } 401 \mathrm{k} \text { and IRA plans the limit on employee contributions is } € 6,800 . \text { In addition employers } \\
\text { can contribute } 1-3 \% \text { of salary matched or } 2 \% \text { fixed. }\end{array}$ \\
\hline
\end{tabular}

Table 3: participation in DC plans

\begin{tabular}{|c|c|}
\hline Australia & $\begin{array}{l}\text { Some } 90 \% \text { of the workforce of around } 10 \text { million are active members of superannuation plans, } \\
\text { nearly all accruing DC benefits. }\end{array}$ \\
\hline Ireland & $\begin{array}{l}\text { While there are } 370,000 \text { members of DC plans plus } 45,000 \text { members of work-based PRSAs, and } \\
\text { these can be assumed to be virtually all in the private sector, it is not easy to estimate } \\
\text { participation rates as the number of active participants is not known. Assuming that } 80 \% \text { are } \\
\text { active and that the private sector workforce is around } 1.8 \text { million (the official } 2.1 \text { million figure } \\
\text { less } 300,000 \text { in the public sector) would give nearly } 20 \% \text { of the private sector workforce actively } \\
\text { participating in a DC plan - almost certainly a higher figure than participate in DB, making the } \\
\text { overall active participation rate significantly. Over } 40 \% \text {. Indeed, participation rates are probably } \\
\text { a bit higher than in the UK. The } 2007 \text { Pensions Green Paper suggested that around } 50 \% \text { of } \\
\text { Irish workers have supplementary pensions. } \\
\text { It is legal for employers to make DC plan membership compulsory and an un-quantified but } \\
\text { significant, and apparently increasing, proportion of employers do so } 110 \text {. }\end{array}$ \\
\hline UK & $\begin{array}{l}2005 \text { data showed } 39 \% \text { of the private sector workforce contributing to a private pension plan, of } \\
\text { which at least half now contribute to a DC plan. Data from the same source shows that } \\
\text { automatic enrolment into DC plans is found mainly with group personal pensions (10\%) with } 3 \% \\
\text { into stakeholder pensions and minimal into trust-based plans. }{ }^{111} \text { This conflicts with a different } \\
\text { survey in the same year that indicated that } 33 \% \text { of DC trust-based members were in plans } \\
\text { operating auto-enrolment. }\end{array}$ \\
\hline USA & $\begin{array}{l}\text { March } 2007 \text { survey statistics }{ }^{112} \text { show that } 61 \% \text { of private sector employees have access to a } \\
\text { retirement savings plan and } 51 \% \text { participate in one. } 85 \% \text { of employers with } 100 \text { or more } \\
\text { employees offer a plan. } 20 \% \text { of employees participate in a DB plan and } 43 \% \text { participate in a DC } \\
\text { plan (meaning that } 8 \% \text { participate in both types). } \\
\text { Auto-enrolment into } 401 \mathrm{k} \text { plans is becoming increasingly prevalent with a } 2007 \text { survey showing } \\
34 \% \text { of employers using automatic enrolment. }{ }^{113} \text { This data is probably skewed towards larger } \\
\text { employers as a larger } 2006 \text { survey shows just } 26 \% \text { of } 401 \mathrm{k} \text { and } 22 \% \text { of combined profit } \\
\text { sharing/401k plans with auto-enrolment, but } 41 \% \text { for }(401 \mathrm{k} \text { ) plans with } 5,000 \text { or more } \\
\text { members. }{ }^{114} \text { Another survey suggests that auto-enrolment is growing rapidly with } 62 \% \text { of } \\
\text { corporate plan sponsors having implemented or currently implementing automatic enrolment }{ }^{115} \text {. }\end{array}$ \\
\hline
\end{tabular}

\footnotetext{
${ }^{110}$ IAPF pension market survey September 2007

111 Department for Work and Pensions Research Report No 329: Employers' Pension Provision Survey 2005, Stephen McKay

${ }^{112}$ US Bureau for Labor Statistics National Compensation Survey, published August 2007

${ }^{113}$ Source: 2007 Trends and Experience in 401(k) Plans survey - Hewitt Associates

${ }^{114}$ Source: PCSA: 50th annual survey of profit sharing and $401 \mathrm{k}$ plans, reflecting 2006 plan experience

${ }^{115}$ Source: Diversified Investment Advisors, Inc.'s Report on Retirement Plans - 2007
} 
Table 4: contribution practices

\begin{tabular}{|c|c|}
\hline Australia & $\begin{array}{l}\text { The basic } 9 \% \text { employer contribution can be supplemented by additional employer contributions or by } \\
\text { employee contributions (through salary sacrifice). There is no available data on the prevalence of the } \\
\text { former but the extensive use of the latter can be deduced from available statistics. There is no } \\
\text { literature to suggest that matching of employee contributions is common. }\end{array}$ \\
\hline Ireland & $\begin{array}{l}\text { Only } 16 \% \text { of employers offering a PRSA make contributions to it. } \\
\text { Most }(80 \%) \text { trust-based schemes have a fixed employer contribution level with around } 10 \% \\
\text { increasing fixed contributions with age and } 10 \% \text { matching employee contributions }{ }^{116} \text {. At least } 88 \% \text { of } \\
\text { trust-based plans receive contributions from members as well as the employer. }\end{array}$ \\
\hline UK & $\begin{array}{l}\text { Statistics from } 2005 \text { showed that there are a significant number of employers that make a contract- } \\
\text { based scheme available but make no contributions - only } 36 \% \text { of employees for whom a stakeholder } \\
\text { pension is available receive employer contributions while only } 24 \% \text { of employers offering them make } \\
\text { contributions with a further } 14 \% \text { where at least one employee makes a contribution nonetheless. } \\
\text { Nearly all employers with group personal pensions make a contribution. On the other hand, } 41 \% \text { of } \\
\text { open trust-based DC schemes do not require employee contributions }{ }^{117} \text {. Where employers and } \\
\text { employee contribute the most common approach is for equally matched contributions, often up to a } \\
\text { maximum employer contribution of } 5 \% \text { for smaller employers. } \\
\text { For very large companies survey data shows average employer contributions (primarily to trust- } \\
\text { based schemes) of } 8.1 \% \text { where matching is not offered and a core (non-matched contribution of } \\
6.1 \% \text { where there is matching (averaging up to } 4 \% \text { on top. } 66 \% \text { of the companies fall into the latter } \\
\text { category. } 21 \% \text { of the schemes increase contributions according to age and } 8 \% \text { according to length } \\
\text { of service. Of the schemes not varying contributions in these ways, the average minimum member } \\
\text { contribution required is } 2.4 \%{ }^{118} \text {. While these contribution levels are likely to be greater than for } \\
\text { smaller employers, the pattern amongst employers generally may be similar. } \\
8 \% \text { of employers with contributory DC pension plans have an arrangement to escalate member } \\
\text { contributions, with the percentages being } 29 \% \text {, } 15 \% \text { and } 6 \% \text { for trust-based, group personal } \\
\text { pensions and stakeholder pension respectively. The likelihood of offering such arrangement also } \\
\text { rises with employer size, being at least } 18 \% \text { for employers with } 100 \text { or more employees - but this } \\
\text { may simply reflect the types of pension offered. }\end{array}$ \\
\hline USA & $\begin{array}{l}\text { A } 2007 \text { survey shows that almost all responding employers ( } 98 \% \text { ) contribute employer money to their } \\
401 \mathrm{k} \text { plans, and two-thirds provide a fixed employer matching contribution. The most common type of } \\
\text { match is } \$ 0.50 \text { per } \$ 1.00 \text { up to a specified percentage of pay (most commonly } 6 \% \text { of pay), reported } \\
\text { by } 26 \% \text { of all plans. } 35 \% \text { of employers offer automatic contribution escalation, where employees can } \\
\text { elect to have their contribution rates automatically increased over time without any additional } \\
\text { action. }{ }^{120} \text { Another source shows that automatic increases in contribution rates are less }(24 \%) \text { in } \\
\text { combined profit sharing } / 401 \mathrm{k} \text { plans than stand-alone } 401 \mathrm{k} \text { plans }(39 \%) \text {. This source could also be } \\
\text { read as implying that around } 7 \% \text { of employers do not contribute to stand-alone } 401 \mathrm{k} \text { plans., but } \\
\text { because participation is around } 20 \% \text { less in these plans and they are on average smaller, the figure } \\
\text { may be consistent with under } 5 \% \text { non-contribution per contributing member } 121 \\
2006 \text { data provides more detail on matching formulae, which are numerous. In plans permitting } \\
\text { employee contributions, the most common formula is a fixed match only, present in } 29.5 \% \text { of plans. } \\
\text { The most common type of fixed match is } \$ 0.50 \text { per } \$ 1.00 \text { up to the first } 6 \% \text { of pay, present in } 32.2 \%\end{array}$ \\
\hline
\end{tabular}

${ }^{116}$ Irish Association of Pension Funds: pension market survey 2007

${ }^{117}$ All figures thus far in this section take from the Department of Work and Pensions Employers' Pension Provision Survey 2005

${ }^{118}$ Watson Wyatt: FTSE 100 defined contribution pension scheme survey 2006

${ }^{119}$ Source: The Employer's Pension Provision Survey 2005, Department of Work and Pensions

${ }^{120}$ Source: US Bureau for Labor Statistics National Compensation Survey, published August 2007.

${ }^{121}$ Source PCSA: 50th annual survey of profit sharing and 401k plans, reflecting 2006 plan experience 


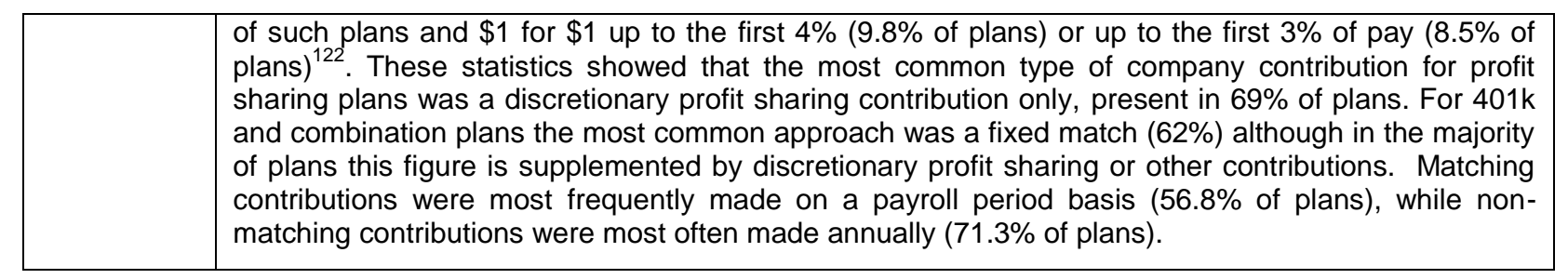

Table 5: contribution levels in practice

\begin{tabular}{|c|c|}
\hline Australia & $\begin{array}{l}\text { Survey data from } 2000 \text { suggested that around } 32 \% \text { of members contribute to their pension plan, with } \\
\text { the likelihood of contribution rising with income and age to some } 38 \% \text { in the } 45-54 \text { age range and } \\
48 \% \text { in the } € 36-49,000 \text { range (and tailing off a bit at higher incomes/ages) }{ }^{123} \text {. In the year to June } \\
2006 \text { employer contributions to superannuation plans totalled } € 46.3 \text { billion, member contributions } \\
\text { totalled } € 29.6 \text { billion and State contributions totalled } € 1 \text { billion }{ }^{124} \text {. (Figures to June } 2007 \text { are } \\
\text { considered to be unreliable as there was a one-off increase in contributions in advance of a change } \\
\text { in taxation rules). These were mostly to DC plans. As there are } 10.2 \text { million employed persons and a } \\
\text { participation rate variously estimated at } 90-95 \% \\
\text { employer and member contributions of around } € 4,900 \text { and } € 3,100 \text {. As Australian average earnings } \\
\text { are around } € 35,000 \text {, this would give average employer contributions of } 14 \% \text { (which may be slightly } \\
\text { on the high side as the small number of DB plans with much higher contributions are included). The } \\
\text { member contribution figures are potentially misleading as they include personal (non-employment) } \\
\text { member contributions, mostly to retail plans. Statistics for industry-wide plans show that member } \\
\text { contributions were } 34 \% \text { of employer contributions in the year to June } 2007 \text { which, after excluding the } \\
\text { apparent } 60 \% \text { increase in contributions that year for tax reasons, would give an average contribution } \\
\text { rate of } 3 \% \text {. This also suggests that the proportion of members contributing has risen considerably } \\
\text { since } 2000 \text {, as otherwise contributing members would be contributing at an average of nearly } 9 \% \text {. }\end{array}$ \\
\hline Ireland & $\begin{array}{l}2007 \text { employer survey data }{ }^{126} \text { gives average (mean) contribution rates into trust-based DC schemes } \\
\text { of } 6 \% \text { for employers and } 5 \% \text { for employees. This reflects a balance between a minority of schemes } \\
\text { with generous employer contributions of up to or above } 10 \% \text { and the median contribution rate of } \\
\text { around } 5 \% \text {. This data is skewed towards larger employers and may therefore over-state contribution } \\
\text { rates. A different survey showed } 76 \% \text { of plans having total contributions in excess of } 10 \% \text { and } 30 \% \\
\text { of plans having total contributions in excess of } 15 \% .{ }^{27} \\
2004 \text { figures show an average aggregate contribution rate of } 7.7 \% \text { to PRSAs for employees of } \\
\text { median age and income but with rates increasing markedly with age and income, up to } 17 \% \text { for the } \\
\text { oldest workers. }{ }^{128} \text { The same source indicates that only } 10 \% \text { of contributions to PRSAs are from } \\
\text { employers but it has to be remembered that many PRSAs are unrelated to employment, except self- } \\
\text { employment. Contributions to RACs appear to be similar, although there are scarcely any employer } \\
\text { contributions, with a } 6.7 \% \text { employee contribution in the median income range }{ }^{129} \text {. For these accounts, }\end{array}$ \\
\hline \multicolumn{2}{|c|}{122 Source PCSA: 50th annual survey of profit sharing and $401 \mathrm{k}$ plans, reflecting 2006 plan experience } \\
\hline \multicolumn{2}{|c|}{${ }^{123}$ Australian Bureau of Statistics Superannuation Coverage and Financial Characteristics, April to June 2000} \\
\hline \multicolumn{2}{|c|}{124 APRA Superannuation Statistics 2007} \\
\hline \multicolumn{2}{|c|}{$\begin{array}{l}{ }^{125} \text { Contributing employees are fewer than the employer workforce because of exclusions for part-time, low paid and } \\
\text { very young/old employees. }\end{array}$} \\
\hline \multicolumn{2}{|c|}{${ }^{126}$ Irish Association of Pension Funds, May 2008} \\
\hline \multicolumn{2}{|c|}{${ }^{127}$ Mercers: Pension Fund Investment Survey 2006} \\
\hline \multicolumn{2}{|c|}{$\begin{array}{l}{ }^{128} \text { Pensions Board: Green Paper on pensions, May 2007. Figures are given for five age ranges and income bands. } \\
\text { The } 7.7 \% \text { applies both to } € 25-35,000 \text { with age } 38-42 \text {, and } € 35-45,000 \text { with } 33-37 \text {. }\end{array}$} \\
\hline \multicolumn{2}{|c|}{$\begin{array}{l}129 \text { Analysis of } 2003 \text { figures in Appendix D of the Pensions Board: Green Paper on pensions shows } 14,146 \\
\text { contributing members in the median } € 40-5000 \text { income range who contributed } € 42.85 \text { million }- \text { hence an } \\
\text { average of } 6.7 \% \text {. A very similar result can be obtained in other middle income ranges including that } \\
\text { encompassing the average industrial wage of } € 33,000 \text {. }\end{array}$} \\
\hline
\end{tabular}




\begin{tabular}{|c|c|}
\hline & $\begin{array}{l}\text { contribution rates increase with very low and very high earnings. Taking account of differences in } \\
\text { timing and other assumptions, it would not be unreasonable to conclude that average employee } \\
\text { contributions do not vary that greatly between type of plan (but employer contributions do). }\end{array}$ \\
\hline UK & 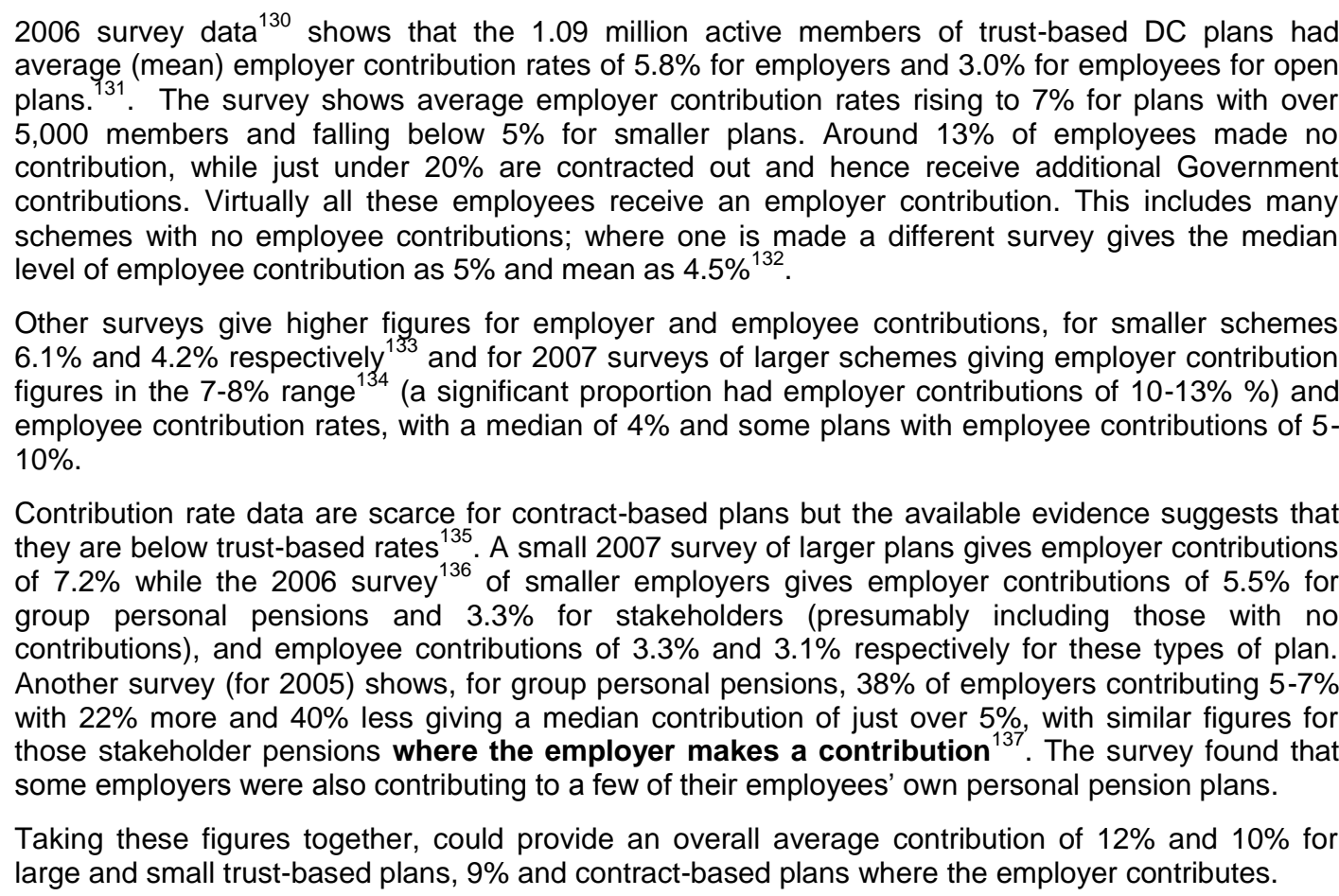 \\
\hline USA & $\begin{array}{l}2006 \text { survey figures for profit sharing and } 401 \mathrm{k} \text { plans showed employee contributions of } 5.4 \% \text { of pay } \\
\text { for lower-paid and } 6.9 \% \text { of pay for higher-paid employees }{ }^{138} \text {. Employer contributions were highest in } \\
\text { profit sharing plans }(9.2 \% \text { of payroll) and lowest in } 401(\mathrm{k}) \text { plans }(3.0 \% \text { of payroll). Employer } \\
\text { contributions averaged } 19.7 \% \text { of total net profit for profit sharing plans and } 11.8 \% \text { of total net profit }\end{array}$ \\
\hline
\end{tabular}

${ }^{130}$ Office of National Statistics, Occupational Pension Scheme Survey 2006 published July 2007

${ }^{131}$ The rates are $5.4 \%$ and $2.5 \%$ respectively for the much smaller number of closed schemes accepting contributions

${ }^{132}$ Department of Work and Pensions Employers' Pension Provision Survey 2005 covers plans with 10 or more members

${ }^{133}$ Association of Consulting Actuaries: smaller schemes 2006 survey, of 460 firms with 250 or fewer employees.

${ }^{134}$ National Association of Pension Funds 2007 survey of its membership (generally larger employers) and PensionDCisions Survey with average size of 7,637 members.

${ }^{135}$ The PensionsDCisions survey mentioned with average size 1,938 members.

${ }^{136}$ Source: Association of Consulting Actuaries: smaller schemes 2006 survey

${ }^{137}$ HMRC data

138 Source: PCSA: 50th annual survey of profit sharing and $401 k$ plans, reflecting 2006 plan experience. The apparent difference between these figures and the EBSA's may reflect the higher contributions made by self-employed and other members of plans not covered by the $50^{\text {th }}$ annual survey. Aggregate EBSA data indicates that aggregate employee contributions are 50\% higher than employer contributions, which would give a contribution rate of $7 \%$ on the basis of the $50^{\text {th }}$ survey's figures for employer contributions. It seems probable that employee contributions are inversely correlated with employer contributions. 


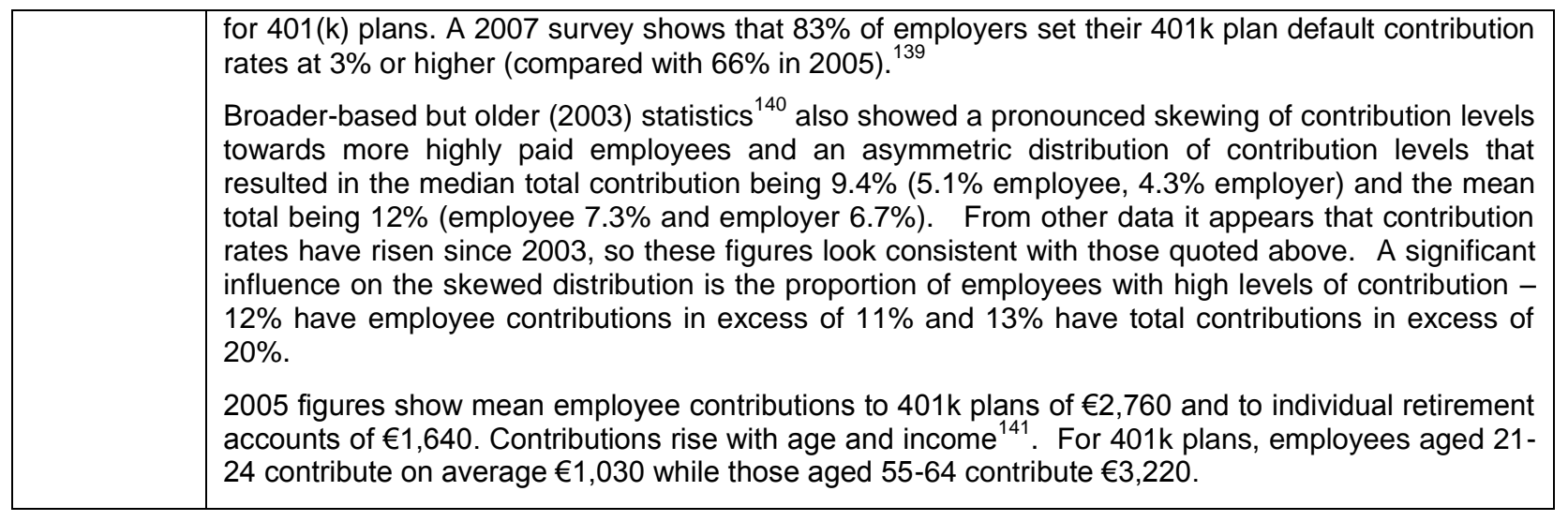

\section{Table 6: investment allocation in DC funds}

\begin{tabular}{|c|c|}
\hline Australia & $\begin{array}{l}\text { The asset allocation in } 2007 \text { for default funds averaged across all plans gives equities } 55 \% \\
\text { (overseas } 24 \% \text { ), property } 10 \% \text {, bonds } 18 \% \text { (overseas } 7 \% \text { ) cash } 8 \% \text {, other (including alternative } \\
\text { investments) } 10 \%{ }^{142} \text {. There is a marked difference between corporate and industry-wide plans } \\
\text { with } 63 \% \text { and } 59 \% \text { respectively in equities, and retail plans with just } 46 \% \text {. Industry-wide funds had } \\
\text { a about } 5 \% \text { higher allocation to property than the other two types. Not surprisingly therefore, retail } \\
\text { plans had a much higher allocation to bonds (27\%) and cash (15\%) than the industry-wide plans } \\
\text { (12\% and } 4 \% \text { respectively). In summary, corporate and industry-wide plans had an allocation to } \\
\text { growth investments of } 70 \% \text { compared with } 52 \% \text { in retail plans. Industry-wide plans had easily the } \\
\text { highest allocation (14\%) to 'other' which would include growth and hedging assets. } \\
\text { Another source, from April } 2006 \text {, shows over } 80 \% \text { of surveyed default funds lying within a range of } \\
70-80 \% \text { in growth assets, with the remainder still falling within the } 60-85 \% \text { range } \\
\text { The overall asset allocation of plans is not available, as asset statistics show the entity in which } \\
\text { funds are invested, which is most commonly (nearly } 70 \% \text { excluding public sector plans) in } \\
\text { wholesale trusts and life office funds. }\end{array}$ \\
\hline Ireland & $\begin{array}{l}\text { The default fund tends to be a passively managed balanced fund with } 65 \% \text { - } 80 \% \text { of assets in } \\
\text { equities and the balance allocated between bonds, cash and property added for diversification }{ }^{143} \text {. } \\
\text { Figures from a } 2006 \text { survey of trustees and sponsors }{ }^{144} \text { shows that } 51 \% \text { of default funds are } \\
\text { consensus (passively managed balanced) followed by actively managed balanced (25\%). It can be } \\
\text { deduced that most schemes not offering fund choice provide a consensus fund. More recent } \\
\text { survey data indicates that } 90 \% \text { of plans offer a balanced fund as a choice, } 74 \% \text { an equity fund, } \\
65 \% \text { cash, } 51 \% \text { fixed income and less than } 18 \% \text { property. Life-styled funds are rapidly gaining } \\
\text { ground being offered by } 31 \% \text { of plans. } \\
\text { No figures are available for overall DC asset allocations. Latest (end } 2007 \text { ) data for all trust-based } \\
\text { plans, of which DC assets are estimated to represent } 26 \% \text {, show } 66 \% \text { in equities }(6 \% \text { Irish, } 63 \%\end{array}$ \\
\hline \multicolumn{2}{|c|}{$\begin{array}{l}\text { Source: PCSA: 50th annual survey of profit sharing and } 401 k \text { plans, reflecting } 2006 \text { plan experience } \\
\text { Congressional Research Service: Retirement Plan Participation and Contributions: Trends from } 1998 \text { to } 2003 \\
\text { published October 2005. }\end{array}$} \\
\hline \multicolumn{2}{|c|}{ Employee Benefit Research Institute figures for 2005} \\
\hline \multicolumn{2}{|c|}{$\begin{array}{l}\text { All the figures in this section come from APRA statistics for } 2007 \text {, which for default funds exclude plans with under } 5 \\
\text { members but include public sector DC plans. Where a plan does not have default strategy the asset allocation of the } \\
\text { largest (or only) fund is used. }\end{array}$} \\
\hline
\end{tabular}




\begin{tabular}{|c|c|}
\hline & $\begin{array}{l}\text { global), } 9 \% \text { property, } 18 \% \text { bonds, } 4 \% \text { cash and } 2 \% \text { 'other' (mostly derivatives). Passive investment } \\
\text { is increasing rapidly, to } 29 \% \text {, but active still predominates. It is possible, however, that passive } \\
\text { investment is more prevalent in DC, with the proportionate growth in DC assets helping to explain } \\
\text { the growth in this area. It is nonetheless reasonable to infer that the majority of DC assets are } \\
\text { actively invested. } \\
\text { For PRSAs the default fund is likely to be a passively managed balanced fund (with heavy equity } \\
\text { component) and life-styling from } 5-10 \text { years before retirement }\end{array}$ \\
\hline UK & $\begin{array}{l}\text { Data from a survey of larger trust-based plans in the UK }{ }^{147} \text { show that around } 80 \% \text { of default funds } \\
\text { are equity funds with the balance mostly multi-asset funds. A few default funds are invested in } \\
\text { bonds/cash with a view to encouraging members to make an active choice of (another) fund, which } \\
\text { seems to work. Some } 75 \% \text { of the funds are passive managed funds with the remainder actively } \\
\text { managed. There is a roughly } 50: 50 \text { split between UK and overseas equities. Nearly all the equity } \\
\text { and multi-asset funds are 'life-styled', with de-risking in half the plans starting at } 10 \text { years before } \\
\text { retirement, a third } 5 \text { years before and the rest with intermediate durations. The availability of life- } \\
\text { style default funds drops rapidly with plan size, being } 61 \% \text { for plans of } 151-250 \text { members and } 36 \% \\
\text { for less than } 50 \text { members }{ }^{148} \text {. Anther source suggests that } 63 \% \text { of DC default funds are life- } \\
\text { styled. }{ }^{149} \\
\text { Turning to fund choice generally, } 95 \% \text { of smaller plans offer a domestic equity fund, at least } 79 \% \\
\text { an international equity fund, at least } 66 \% \text { a bond fund, } 96 \% \text { a cash fund, } 92 \% \text { a balanced fund, } \\
70 \% \text { with profits and } 88 \% \text { a life-style fund. These proportions all rise with plan size, so that it is } \\
\text { likely that most large funds offer the full range. } 64 \% \text { of these plans offer a choice of fund manager, } \\
\text { again rising rapidly with plan size }{ }^{150} \text {. } \\
\text { Stakeholder (contract-based) pensions appear to differ somewhat to some extent from trust-based } \\
\text { plans with a preponderance (54\%) of (mostly) actively managed balanced funds ( } 70-80 \% \text { in } \\
\text { equities), with a smaller number of passively managed equity funds and a few with-profits funds } \\
\text { (actively managed } 60 \% \text { in equities) } \text { f }^{151} \text {. They are required to be life-styled (and indeed half were in } \\
2004 \text { before this requirement came in). Life-styling started mostly } 5 \text { but sometimes } 8 \text { or } 10 \text { years } \\
\text { before retirement. }\end{array}$ \\
\hline USA & $\begin{array}{l}\text { US data is complicated because many members spread their investments across a number of } \\
\text { funds and because fewer use default funds. Therefore the most interesting statistics relate to the } \\
\text { proportion of assets held in different fund types. } \\
\text { Nearly all (say } 97 \% \text { ) of } 401 \mathrm{k} \text { plans offer domestic equity funds }{ }^{152} \text {. Equity funds have just over half } \\
\text { the assets for plans with fewer than } 5,000 \text { members, and } 44 \% \text { for funds with at least } 5,000 \\
\text { members. These assets are predominantly (at least } 75 \% \text { ) in actively managed funds and }(80 \%) \\
\text { domestic funds. Although balanced bond/stock funds are widely available }(64.8 \% \text { of plans), only } \\
8 \% \text { of investments are in these funds }{ }^{153} \text {. Statistics for funds with over } 5,000 \text { members differ } \\
\text { somewhat as a higher proportion of their assets ( } 15 \% \text { ) is invested in company stock funds than is } \\
\text { the case for all funds ( } 3.4 \% \text { ) - company stock appears broadly substitute for equity. While over } \\
80 \% \text { of plans make bond or cash funds available, these have just } 9 \% \text { of assets. Cautious } \\
\text { investment is also reflected in the } 9 \% \text { of assets in stable value funds, available in nearly } 60 \% \text { of }\end{array}$ \\
\hline
\end{tabular}

${ }^{146}$ Evidence from marketing literature for Irish Life, New Ireland Assurance and Eagle Star PRSAs

${ }^{147}$ PensionDCisions 2008 Default Investment Strategy Survey

${ }^{148}$ Association of Consulting Actuaries smaller forms survey 2006

${ }^{149}$ National Association of Pension Funds 2006

${ }^{150}$ Association of Consulting Actuaries: smaller schemes 2006 survey, of 460 firms with 250 or fewer employees.

${ }^{151}$ The Stakeholder Pension Lottery: An Analysis of the Default Funds in UK Stakeholder Pension Schemes by David Blake, Alistair Byrne, Andrew Cairns and Kevin Dowd1 using data from 2004

1522001 data from “The Adequacy of Investment Choices Offered By $401 \mathrm{~K}$ Plans” Edwin J. Elton, Martin J. Gruber and Christopher R. Blake. Other data indicates that this position will not have changed materially since.

${ }^{153}$ Source: PCSA: 50th annual survey of profit sharing and 401k plans, reflecting 2006 plan experience 


\begin{tabular}{|c|}
\hline 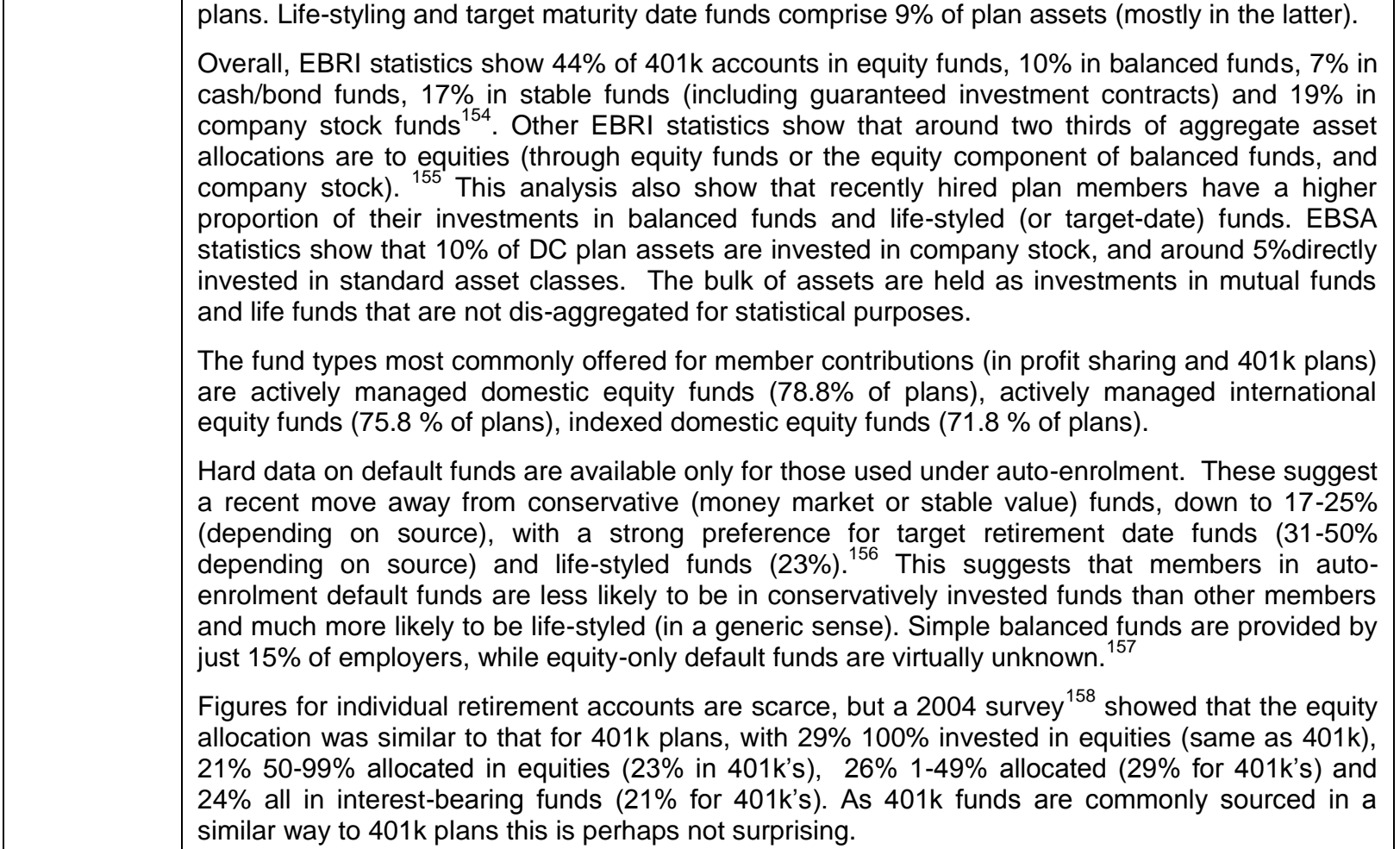 \\
\hline
\end{tabular}

Table 7: disclosure requirements for fees and charges

\begin{tabular}{|c|l|}
\hline Australia & $\begin{array}{l}\text { DC pension plans must disclose their fees in a product disclosure statement. The regulations } \\
\text { require up to five types of fees to be disclosed (contribution fee, annual management fee, } \\
\text { establishment fee, withdrawal fee and termination fee). To make comparison easier, contribution } \\
\text { and management fees are based on an assumed annual contribution and fund balance of } € 3,000 \\
\text { and } € 30,000, \text { respectively to arrive at a cost of fund. This information is made publicly available on } \\
\text { the (conduct of business) supervisor's website. Disclosure is required of any other fees, such as } \\
\text { performance fees, but not bid-offer spread as on fund transactions. }\end{array}$ \\
\hline Ireland & $\begin{array}{l}\text { PRSA providers are required to disclose regularly all charges and commissions, and changes } \\
\text { thereto. Trust-based plans with investment choice must disclose a description of the charges } \\
\text { levied on each investment alternative that reduce contributions on their investment and/or the rate } \\
\text { of return to members. }\end{array}$ \\
\hline UK & \begin{tabular}{l} 
Stakeholder plan providers are required to disclose the fees charged and any changes thereto. \\
\hline
\end{tabular}
\end{tabular}

${ }^{154}$ Employee Benefit Research Institute (EBRI), Issue Brief August 2007, 401(k) Plan Asset Allocation, Account Balances, and Loan Activity in 2006 By Jack VanDerhei, Temple University and EBRI Fellow; Sarah Holden, ICI; Craig Copeland and Luis Alonso, EBRI

${ }^{155}$ Source: EBRI/ICI database 2006

156 The sources are Bureau for Labor Statistics National Compensation Survey, published August 2007 and PCSA: 50th annual survey of profit sharing and $401 \mathrm{k}$ plans, reflecting 2006 plan experience - the percentage for life-styled funds comes from the latter.

${ }^{157}$ Source: PCSA: 50th annual survey of profit sharing and $401 \mathrm{k}$ plans, reflecting 2006 plan experience.

158 Source: Employee Benefit Research Institute Retirement Plan Participation and Asset Allocation, 2004, published February 2007 


\begin{tabular}{|c|c|}
\hline USA & $\begin{array}{l}\text { Where a plan gives investment choice the plan administrator should provide members with copies } \\
\text { of documents describing investment management and other fees associated with each of the } \\
\text { investment alternatives available (i.e., a prospectus). The plan administrator should also provide a } \\
\text { description of any transaction fees and expenses that will be charged against the account balance } \\
\text { in connection with the direction of investments. } \\
\text { There is no requirement for routine disclosure to members of fees actually incurred once they have } \\
\text { joined the plan, although annual account statements may show them. The plan annual report } \\
\text { shows plan administrative expenses but not charges netted off from the member's account } \\
\text { (notably investment charges). } \\
\text { The regulator considers these requirements to be insufficient and is encouraging an amendment to } \\
\text { ERISA that would make for annual and specific disclosure of full information on fees. The } \\
\text { Government Accountability Office has concluded that: the information on fees that } 401(\mathrm{k}) \text { plan } \\
\text { sponsors are required by law to disclose is limited and does not provide for an easy comparison } \\
\text { among investment options. ERISA requires that plan sponsors provide participants with certain } \\
\text { disclosure documents, but these documents are not required to contain information on fees borne } \\
\text { by individual participants. Additional fee disclosures are required for certain--but not all--plans in } \\
\text { which participants direct their investments. These disclosures are provided to participants in a } \\
\text { piecemeal fashion and do not provide a simple way for participants to compare plan investment } \\
\text { options and their fees. The regulator has authority under ERISA to oversee } 401 \text { (k) plan fees and } \\
\text { certain types of business arrangements that could affect fees, but lacks the information it needs to } \\
\text { provide effective oversight. }\end{array}$ \\
\hline
\end{tabular}

Table 8: fees and charges in practice

\begin{tabular}{|c|c|}
\hline Australia & $\begin{array}{l}2007 \text { APRA statistics for investment and operating expenses show the aggregate position for } \\
\text { company plans as } 0.67 \% \text { of assets, industry-wide plans } 0.85 \% \text { and retail plans } 0.93 \% \text {. Taking } \\
\text { investment management costs on their own, the figures are } 0.26 \%, 0.27 \% \text { and } 0.41 \% \text {, leaving } \\
\text { other (mostly administrative) charges at } 0.39 \%, 0.58 \% \text { and } 0.52 \% \text { respectively. The higher charges } \\
\text { in the latter two categories may well represent the predominance of public offer funds with } \\
\text { marketing expenses and other expenses associated with operating across a large number of } \\
\text { employers - furthermore some employer-sponsored plans may pass some administrative costs } \\
\text { onto the employer). There may, that said, be further hidden charges not shown in APRA statistics } \\
\text { that are netted off within investment returns. } \\
\text { Turning to the fees actually levied, plans are obliged to disclose the overall cost of contributing } \\
€ 3,000 \text { a year to a fund with a balance of } € 30,000 \text {. This 'cost of fund' varies considerably, as the } \\
\text { following data from } 2006 \text { shows }{ }^{160} \text { : } \\
\text { - For public offer industry-wide plans, the mean cost is } € 285 \text { and the median } € 260 \text {. The } \\
\text { lower quartile is } € 230 \text { and the upper quartile } € 335 \text {. } \\
\text { - Industry-wide plans that are not public offer are slightly more expensive than those that } \\
\text { are public offer, with mean cost of } € 290 \text { and the median } € 305 \text {. The lower quartile is } € 230 \\
\text { and the upper quartile } € 320 \text {. } \\
\text { - Fees are higher for retail public offer plans, with a mean cost of } € 480 \text { and the median } \\
€ 540 \text {. The lower quartile is } € 280 \text { and the upper quartile } € 630 \text {. } \\
\text { - Company plans are cheapest with mean cost of } € 260 \text { and median } € 230 \text {. The lower } \\
\text { quartile is } € 200 \text { and upper quartile } € 310 \\
\text { Breaking the cost of fund down by fee type shows that the main cost element is the } \\
\text { annual management charges, responsible for well over } 80 \% \text { of the cost of fund. }\end{array}$ \\
\hline
\end{tabular}

${ }^{159}$ US Government Accountability Office: Private Pensions: Changes Needed to Provide 401(k) Plan Participants and the Department of Labor Better Information on Fees GAO-07-21 November 2006

${ }^{160}$ Australian Securities and investments Commission: Monitoring superannuation fees and costs (October 2005 to June 2006) published November 2006 


\begin{tabular}{|c|c|}
\hline & $\begin{array}{l}\text { Fees other than annual management charges and contribution based charges are very } \\
\text { low, and often zero. For instance, } 95 \% \text { of plans have no establishment charge. } \\
\text { Treating the cost of fund like an annual management charge would give a headline comparative } \\
\text { figure of } 1.8 \% \text { charges for the median retail fund and } 0.75-0,95 \% \text { for median plans in the other } \\
\text { categories. Of course these figures will tend to overstate the charges for (longer-serving) members } \\
\text { with larger balances and understate them for newer members or those with smaller balances. The } \\
\text { fees charged for the simplest product offered by each plan can be significantly less than the } \\
\text { average fees. These products are probably reflected in the large spike of products with fees } \\
\text { around } € 240 \text {, which would give a headline annual management charge of } 0.8 \% \text { for the lower cost } \\
\text { funds most members are likely to be in (for instance by default). } \\
\text { Overall the big outliers are retail plans. This probably reflects the commercial as opposed to not for } \\
\text { profit basis of retail plans along with the much wider fund choice they offer and a greater likelihood } \\
\text { of offering actively rather than passively managed funds. Company plans tend to offer the least } \\
\text { choice and to have much smaller marketing overheads. }\end{array}$ \\
\hline Ireland & $\begin{array}{l}\text { There is minimal data for Ireland, but it might be reasonable to assume that the position is not that } \\
\text { different from the UK, below, given the similarity of systems and industry participants. The current } \\
\text { regulatory cap on standard PRSA pension charges in would produce a cost of fund, as calculated } \\
\text { in Australia, of } 1.2 \% \text {, but unlike in the UK there is no evidence of providers under-cutting this level. } \\
\text { Furthermore, non-standard PRSAs are said to have higher fees. The level of fees may well, } \\
\text { therefore be somewhat higher than in the UK }\end{array}$ \\
\hline UK & $\begin{array}{l}\text { For trust-based plans the only charges borne by the members are investment management fees } \\
\text { as the employers pay for administration - where an often quoted figure is } 0.3 \% \text { of plan balances. } \\
\text { Limited survey data }{ }^{161} \text { shows that investment management fees average } 0.27 \% \text { (of fund } \\
\text { balances), with a range from zero (reputedly due to the sponsor's wider relationship with the } \\
\text { investment manager) to } 1 \% \text {. The most common rates are } 0.15 \% \text { and } 0.5 \% \text { generally reflecting } \\
\text { whether the fund is passively or actively managed (for which the averages are } 0.2 \% \text { and } 0.51 \% \\
\text { respectively). The survey finds some correlation between the percentage fees charged for } \\
\text { passively managed funds and the plan size (in terms of membership and assets). Hence none of } \\
\text { the plans with passively managed assets in excess of } € 250 \text { million had a fee in excess of } 0.2 \% \text {. } \\
\text { The costs of contract-based plans are higher than those for trust-based because of the sales and } \\
\text { marketing costs incurred by the provider. These costs reduce with the size of plan concerned so } \\
\text { that plan charges also decrease with size. Hard data is scarce about the annual management } \\
\text { charges paid by members of UK contract-based plans because rates are negotiated with individual } \\
\text { employers. It would appear that charging structures for group personal pensions have been } \\
\text { largely aligned with those for the stakeholders offered by the same provider. However, while } \\
\text { stakeholder pensions are limited to charging the annual management charge (and some } \\
\text { investment dealing costs), group personal pension plans can and often do have initial charges and } \\
\text { withdrawal charges. Annual management charges appear to be no more than } 0.8 \% \text { for medium } \\
\text { and large plans - significantly below the } 1.5 \% \text { cap on stakeholder fees during the first five years } \\
\text { (and } 1 \% \text { thereafter). One source }{ }^{162} \text { gives charges for group personal pensions ranging from } 0.5 \% \\
\text { to } 1.5 \% \text { (with presumably much of the variation being plan-size related). }\end{array}$ \\
\hline USA & $\begin{array}{l}\text { It is generally recognised that there is limited transparency of DC plan, especially } 401 \mathrm{k} \text {, fees and } \\
\text { that there is a wide range of fee structures and fee types, with in particular fees charged flat rate } \\
\text { regardless of plan size, spread across the number of plan members, as a percentage of assets } \\
\text { and for specific services. The charges can come separately from the different service providers }\end{array}$ \\
\hline
\end{tabular}

\footnotetext{
${ }^{161}$ PensionDCisions: Default strategies in context 2007. This data covers a few large contract-based plans although most of the 42 plans are trust-based. The total membership of these plans is around $15 \%$ of trust-based DC plan membership.

${ }^{162}$ Employeebenefits.co.uk on-line information from November 2007
} 


\begin{tabular}{|l|l|}
\hline $\begin{array}{l}\text { involved in the plan. There are suggestions that total fees are commonly over } 1 \% \text { of asset values, } \\
2 \% \text { or even } 3 \% \\
\text { have difficulty in tracking down. }\end{array}$ \\
$\begin{array}{l}\text { Practice varies as to whether the employer pays the administrative costs of } 401 \mathrm{k} \text { and profit sharing } \\
\text { plans }{ }^{164} .91 \% \text { pay the relevant costs of internal administrative staff, } 66 \% \text { pay for communications } \\
\text { with employees, } 58 \% \text { investment consultant fees and } 53 \% \text { plan record-keeping fees. On the other } \\
\text { hand, only } 24 \% \text { pay investment manager fees, although a further } 10 \% \text { share them with the plan }{ }^{165} \text {. } \\
\text { Department of Labor statistics show that administrative expenses incurred by DC plans with over } \\
100 \text { members come to just } 0.09 \% \text { of assets. These figures exclude administrative costs borne by } \\
\text { the employer. Another source gives } 39 \% \text { of companies paying less than } 0.2 \% \text { and } 28 \% \text { paying } \\
0.2-0.4 \%{ }^{166} \text {. Taking plan and employer costs together gives a figure for total administrative costs } \\
\text { similar to or just above the } 0.3 \% \text { assumed in the UK These figures exclude investment } \\
\text { management costs which are netted off. } 2005 \text { Data from mutual funds, in which } 401 \mathrm{k} \text { plans are } \\
\text { heavy investors, shows investment management charges of around } 0.72 \% \text { some which may be } \\
\text { bundled administrative charges. }\end{array}$ \\
$\begin{array}{l}\text { There is no recent data on the full range of fees charged for DC plans, but a paper from } 1998 \\
\text { indicated that establishment fees were common and relatively large and that investment } \\
\text { management fees represented } 75-90 \% \text { of total fees. On the basis of the costs of administration } \\
\text { given above this could easily result in an investment management fee around } 0.8 \%-2 \% \text { of asset } \\
\text { value. The paper estimated on the basis of earlier (mid } 90 \text { s) data that for a large plan }(2-4,000 \\
\text { members) the total fee was in the range } 0.99 \%-1.10 \% \text {, while for a smaller plan (100 members) it } \\
\text { was in the range } 1.3 \%-1.4 \% \text {. Other quotation data for a } 100 \text { member plan from just } 17 \text { providers } \\
\text { showed fees varying from } 0.57 \% \text { to } 2.14 \% \text {. Fees may have fallen since, (given the costs outlined } \\
\text { above, although Congressional testimony already referred to would suggest otherwise. }\end{array}$ \\
\hline
\end{tabular}

163 The last of these figures, along with the next quote, comes from evidence to a March 2007 Congressional Enquiry into $401 \mathrm{k}$ fees given by Matthew Hutcheson, pension consultant and independent pension fiduciary.

164 The data in this section, unless separately referenced, comes from PCSA: 50th annual survey of profit sharing and $401 k$ plans, reflecting 2006 plan experience.

${ }^{165}$ Source: PCSA: 50th annual survey of profit sharing and 401k plans, reflecting 2006 plan experience

${ }^{166}$ Source: PCSA: 50th annual survey of profit sharing and 401k plans, reflecting 2006 plan experience

167 Investment Company Institute, "The Economics of Providing 401(k) Plans: Service Fees and Expenses" (Research Fundamentals, November 2006).

${ }^{168}$ Study of 401(k) Plan Fees and Expenses published by Department of Labor April 1998 
Table 9: regulated retirement options

\begin{tabular}{|c|c|c|}
\hline \multirow[t]{9}{*}{ Australia } & \multicolumn{2}{|c|}{$\begin{array}{l}\text { The full balance in the pension plan may be taken as a cash sum, or alternatively the money can } \\
\text { be transferred to an approved deposit fund or employee rollover fund or kept in the superannuation } \\
\text { fund so long as it is progressively drawn down. The lump sum can be used to buy an annuity, but } \\
\text { although some plans offer this facility, few members in practice buy an annuity. It can also be } \\
\text { used to buy an income drawdown product, known until September } 2007 \text { as an allocated annuity } \\
\text { (from a life insurer) or allocated pension (from a superannuation plan), which is much more } \\
\text { common than a conventional annuity. (The terminology has now changed to 'account-based } \\
\text { pension or anuity'.) Alternatively the balance can be held in a superannuation plan or approved } \\
\text { deposit fund to be accessed at will. Where the pension is held in a plan or paid down through } \\
\text { some form of income drawdown tax rules since September } 2007 \text { have required that the minimum } \\
\text { payout each year should be as follows: }\end{array}$} \\
\hline & Age of Pensioner & Percentage of Account balance \\
\hline & Under 65 & 4 \\
\hline & $65-74$ & 5 \\
\hline & $75-79$ & 6 \\
\hline & $80-84$ & 7 \\
\hline & $85-89$ & 9 \\
\hline & $90-94$ & 11 \\
\hline & 95 or more & 14 \\
\hline \multirow[t]{2}{*}{ Ireland } & \multirow{2}{*}{\multicolumn{2}{|c|}{$\begin{array}{l}\text { The tax-free cash lump sum in a trust-based plan is limited to } 1.5 \text { times final annual salary for } \\
\text { workers for with at least } 20 \text { years service, with reduced rates for those with shorter service. There } \\
\text { is a limit of } 25 \% \text { of the balance for contract-based plans. For members of trust-based plans (and } \\
\text { retirement annuity contracts) the remainder of the balance has to buy an annuity (almost always } \\
\text { from a commercial provider rather than a pension paid through the plan). } \\
\text { Members of PRSAs, holders of AVC balances and certain company directors are allowed to take } \\
\text { taxable cash if the member has a guaranteed pension income for life from other sources of at least } \\
€ 12,700 \text { a year, or if the guaranteed income for life is less than that if } € 12,700 \text { a year, invest the } \\
\text { first } € 63,500 \text { of the balance in either an annuity or an Approved Minimum Retirement Fund } \\
\text { (AMRF), a regulated income drawdown product which leaves theh capital untouched until age } 75 \text {. } \\
\text { Instead of taking taxable cash they may but the balance into an Approved Retirement Fund (ARF) } \\
\text { which is a more flexible income drawdown product. (The AMRF turns into an ARF at age } 75 \text { ). In } \\
\text { any event, they must draw down out at least } 3 \% \text { of the balance each year. }\end{array}$}} \\
\hline & & \\
\hline \multirow[t]{2}{*}{ UK } & \multirow{2}{*}{\multicolumn{2}{|c|}{$\begin{array}{l}\text { the tax-free cash lump sum that can be taken is limited to } 25 \% \text { of the balance, except for small } \\
\text { accumulated balances where the full amount can be taken as cash. The remainder must be used } \\
\text { either to buy an annuity or, since } 2006 \text {, a (FSA) regulated income drawdown product ("unsecured } \\
\text { pension"). This product is limited to paying out no more than } 120 \% \text { of the amount of an equivalent } \\
\text { level single lifetime annuity and the balance must be either be annuitised at } 75 \text { or moved to an } \\
\text { 'alternatively secured pension' with tighter rules on payout, including a a payout limit of up to } 70 \% \\
\text { of the equivalent level single lifetime annuity . } \\
\text { This option is not yet commonly allowed by trust-based plans, and individuals circumvent this by } \\
\text { transferring to a contract-based plan (usually a SIPP) just before retirement. In practice, members } \\
\text { taking up this option are advised to take professional advice and only those with large balances } \\
\text { are expected to take it up. }\end{array}$}} \\
\hline & & \\
\hline USA & \multicolumn{2}{|c|}{$\begin{array}{l}\text { Requirements depend on the plan rules. There is a legal requirement that plans offer a transfer } \\
\text { into an individual retirement account (where it can be freely accessed). Other than that, plans are } \\
\text { free to offer lump sums, annuities, income drawdown or retention of the balance in the plan itself. } \\
\text { Some plans specify that an annuity must be bought with the balance, but it is more usual for the } \\
\text { plan to allow a cash withdrawal or transfer to an individual retirement account. }\end{array}$} \\
\hline
\end{tabular}

